\title{
The governing processes and timescales of stratosphere-to-troposphere transport and its contribution to ozone in the Arctic troposphere
}

\author{
Q. Liang ${ }^{1,2}$, A. R. Douglass ${ }^{1}$, B. N. Duncan ${ }^{1,3}$, R. S. Stolarski ${ }^{1}$, and J. C. Witte ${ }^{1,4}$ \\ ${ }^{1}$ NASA Goddard Space Flight Center, Atmospheric Chemistry and Dynamics Branch, Code 613.3, \\ Greenbelt, MD 20771, USA \\ ${ }^{2}$ Oak Ridge Associated Universities, NASA Postdoctoral Program, Oak Ridge, TN 37831, USA \\ ${ }^{3}$ Goddard Earth Sciences \& Technology Center, University of Maryland, Baltimore County, MD, USA \\ ${ }^{4}$ Science Systems and Applications Inc., Lanham, MD, USA
}

Received: 2 October 2008 - Published in Atmos. Chem. Phys. Discuss.: 14 November 2008

Revised: 23 April 2009 - Accepted: 29 April 2009 - Published: 11 May 2009

\begin{abstract}
We used the seasonality of a combination of atmospheric trace gases and idealized tracers to examine stratosphere-to-troposphere transport and its influence on tropospheric composition in the Arctic. Maximum stratosphere-to-troposphere transport of $\mathrm{CFCs}$ and $\mathrm{O}_{3}$ occurs in April as driven by the Brewer-Dobson circulation. Stratosphere-troposphere exchange (STE) occurs predominantly between $40^{\circ} \mathrm{N}$ to $80^{\circ} \mathrm{N}$ with stratospheric influx in the mid-latitudes $\left(30-70^{\circ} \mathrm{N}\right)$ accounting for $67-81 \%$ of the air of stratospheric origin in the Northern Hemisphere extratropical troposphere. Transport from the lower stratosphere to the lower troposphere (LT) takes three months on average, one month to cross the tropopause, the second month to travel from the upper troposphere (UT) to the middle troposphere (MT), and the third month to reach the LT. During downward transport, the seasonality of a trace gas can be greatly impacted by wet removal and chemistry. A comparison of idealized tracers with varying lifetimes suggests that when initialized with the same concentrations and seasonal cycles at the tropopause, trace gases that have shorter lifetimes display lower concentrations, smaller amplitudes, and earlier seasonal maxima during transport to the LT. STE contributes to $\mathrm{O}_{3}$ in the Arctic troposphere directly from the transport of $\mathrm{O}_{3}$ and indirectly from the transport of $\mathrm{NO}_{\mathrm{y}}$. Direct transport of $\mathrm{O}_{3}$ from the stratosphere accounts for $78 \%$ of $\mathrm{O}_{3}$ in the Arctic UT with maximum contributions occurring from March to May. The stratospheric contribu-
\end{abstract}

Correspondence to: Q. Liang

(Qing.Liang@nasa.gov) tion decreases significantly in the MT/LT (20-25\% of total $\mathrm{O}_{3}$ ) and shows a very weak March-April maximum. Our $\mathrm{NO}_{\mathrm{x}}$ budget analysis in the Arctic UT shows that during spring and summer, the stratospheric injection of $\mathrm{NO}_{\mathrm{y}}$-rich air increases $\mathrm{NO}_{\mathrm{x}}$ concentrations above the 20 pptv threshold level, thereby shifting the Arctic UT from a regime of net photochemical ozone loss to one of net production with rates as high as $+16 \mathrm{ppbv} / \mathrm{month}$.

\section{Introduction}

Ozone $\left(\mathrm{O}_{3}\right)$ plays a vital role in the oxidation capacity of the troposphere and it is an important greenhouse gas, particularly in the upper troposphere (UT). An increase in tropospheric ozone was responsible for one-third $\left(0.4-0.5^{\circ} \mathrm{C}\right)$ of the observed warming trend between 1890-1990 in the Arctic during winter and spring (Shindell et al., 2006). The origin, trends, and distribution of ozone in the Arctic have important implications for both air quality and climate change.

Ozone measurements in the Arctic troposphere show a clear annual cycle with a maximum in spring (Penkett and Brice, 1986; Oltmans and Levy, 1994; Simmonds et al., 1997; Logan et al., 1999). The origin of the spring ozone maximum in the Northern Hemisphere (NH) is still not wellunderstood (Monks, 2000), despite the extensive observational and modeling efforts in the last few decades to quantify the relative contribution of the stratosphere-to-troposphere transport (STT) of ozone, in situ photochemical production and destruction of tropospheric ozone. This springtime maximum has been attributed to both maximum stratospheric flux

Published by Copernicus Publications on behalf of the European Geosciences Union. 
(e.g., Danielsen and Mohnen, 1977; Oltmans, 1981; Levy et al., 1985; Logan, 1985, 1999; Wang et al., 1998; Stohl et al., 2003) and active photochemical production (e.g., Liu et al., 1987; Wang et al., 1998; Yienger et al., 1999). Surface measurements of radioactive debris $\left({ }^{90} \mathrm{Sr}\right)$ and Beryllium-7 $\left({ }^{7} \mathrm{Be}\right)$ also show a spring maximum associated with the seasonal cycle of stratosphere-troposphere exchange (STE) (e.g. Fry et al., 1960; Dibb et al., 1994). However, the spring peak is not unique to chemical species of stratospheric origin. Observations at Mace Head, Ireland show a spring maximum in many trace gases, e.g., carbon monoxide (CO), carbon dioxide $\left(\mathrm{CO}_{2}\right)$, nitrous oxide $\left(\mathrm{N}_{2} \mathrm{O}\right)$, and methane $\left(\mathrm{CH}_{4}\right)$, whether they are related to STE or not (Derwent et al., 1998). Interestingly, the isotopic ratio of ${ }^{10} \mathrm{Be} /{ }^{7} \mathrm{Be}$ indicates a twofold increase of stratospheric influence at the surface at Alert during late summer, not spring (Dibb et al., 1994).

The extensive measurements from aircraft campaigns also complicate the conventional understanding of the impact of STE. Airborne measurements obtained during the Tropospheric Ozone Production about the Spring Equinox (TOPSE) experiment (Atlas et al., 2003) show strong stratospheric intrusions with elevated levels of ozone mostly in the UT. The field observations revealed that the spring ozone maximum in the free troposphere is mostly due to in situ photochemistry (Atlas et al., 2003; Browell et al., 2003). In contrast, significant enhancements of stratospheric $\mathrm{O}_{3}$, reactive nitrogen $\left(\mathrm{NO}_{\mathrm{y}}\right)$ and ${ }^{7} \mathrm{Be}$ were observed in the Arctic middle troposphere (MT) in summer during the NASA Arctic Boundary Layer Expedition (ABLE) 1988 (ABLE 3A) and 1990 (ABLE 3B) expeditions (e.g. Harriss et al., 1992, 1994; Browell et al., 1992, 1994; Dibb et al., 1992; Talbot et al., 1992, 1994). The more recent Intercontinental Chemical Transport Experiment - North America Phase A (INTEXA) mission also showed significant stratospheric influence in the Northern Hemisphere $(\mathrm{NH})$ mid-latitudes during summer (Thompson et al., 2007; Liang et al., 2007) and that the stratospheric influence was more persistent and prevalent than previously considered (Thompson et al., 2007).

Recent studies by Nevison et al. (2004) and Liang et al. (2008) found that chlorofluorocarbons (CFCs) and $\mathrm{N}_{2} \mathrm{O}$, species whose seasonal cycle is influenced by STE, show a spring minimum (maximum stratospheric influence) in the NH extra-tropical UT. The minimum propagates slowly to the lower troposphere (LT) and occurs three months later in late summer near the surface. This suggests slower downward transport following STE than originally expected. Thus LT measurements of short-lived trace gas may have little dependence on STE as the amplitude and phase of its seasonal cycle that is associated with STE might diminish significantly due to chemical destruction in the troposphere.

Stratospheric injection is also an important source of nitrogen oxides $\left(\mathrm{NO}_{\mathrm{x}}=\mathrm{NO}+\mathrm{NO}_{2}\right)$ in the Arctic troposphere. $\mathrm{NO}_{\mathrm{x}}$ plays a critical role in tropospheric ozone photochemistry. A typical critical range of $\mathrm{NO}_{\mathrm{x}}$ is $10-150 \mathrm{pptv}$, which together with levels of $\mathrm{O}_{3}$ and $\mathrm{H}_{2} \mathrm{O}$, determines $\mathrm{O}_{3}$ production effi- ciency in the background troposphere (Lin et al., 1988; Sillman et al., 1990). Though the total stratospheric contribution $(0.64 \mathrm{TgN} / \mathrm{yr})$ is small as compared to the global tropospheric $\mathrm{NO}_{\mathrm{x}}$ budget $(\sim 40 \mathrm{TgN} / \mathrm{yr})$, the injection of $\mathrm{NO}_{\mathrm{y}}$-rich stratospheric air is concentrated in the polar UT during spring and summer (Levy et al., 1999). During this time, $\mathrm{NO}_{\mathrm{x}}$ mixing ratios in the Arctic free troposphere increase from the $\sim 10$ 20 pptv to $\sim 30$ pptv (Stroud et al., 2003). Near the lower end of the critical range (10-20 pptv), production of ozone is slow and net destruction dominates (Klonecki and Levy, 1997). As $\mathrm{NO}_{\mathrm{x}}$ increases to $150 \mathrm{pptv}$, production of ozone increases and the chemical ozone tendency first changes from negative to positive and then increases rapidly with a linear dependence on $\mathrm{NO}_{\mathrm{x}}$ concentrations (Klonecki and Levy, 1997; Jaeglé et al., 1999). Therefore, a quantitative understanding of the stratospheric contribution to $\mathrm{NO}_{\mathrm{x}}$ in the Arctic troposphere is important in understanding $\mathrm{NO}_{\mathrm{x}}$ seasonal variations and the associated impacts on the seasonal transition in ozone photochemical production efficiency. Previous measurements have documented the presence of elevated $\mathrm{NO}_{\mathrm{y}}$ in the Arctic troposphere during winter-spring (Bottenheim and Gallant, 1989; Honrath and Jaffe, 1992; Honrath et al., 1996; Wang et al., 2003). Understanding the recycling between $\mathrm{NO}_{\mathrm{x}}$ and its reservoir species, peroxyacetyl nitrate (PAN) and nitric acid $\left(\mathrm{HNO}_{3}\right)$, is crucial to unraveling the $\mathrm{O}_{3}-\mathrm{NO}_{\mathrm{x}}$ photochemistry in the Arctic.

In past literature, STE and STT are sometimes used interchangeably. For this study, it is important to distinguish between the two. We use STE to refer to mass exchange between the stratosphere and the troposphere that occurs at the tropopause, following Stohl et al. (2003). We expand the conventional definition of STT to include the stratosphereto-troposphere transport and the subsequent transport within the troposphere.

In this study, we investigate STT and its impact on tropospheric $\mathrm{O}_{3}$ and $\mathrm{NO}_{\mathrm{x}}$ chemistry using a combination of atmospheric trace gases and dynamic tracers with the Global Modeling Initiative (GMI) chemistry transport model (CTM). A model description and evaluation are given in Sects. 2 and 3, respectively. A discussion of the dynamics and timescales of STT is presented in Sect. 4. In Sect. 5, we examine and quantify the influence of STE on tropospheric composition. We consider both the primary effect, direct transport of stratospheric $\mathrm{O}_{3}$ into the troposphere, and secondary effect, in situ formation of $\mathrm{O}_{3}$ from $\mathrm{NO}_{\mathrm{y}}$ of stratospheric origin. Conclusions are presented in Sect. 6.

\section{Model description}

\subsection{The Global Modeling Initiative Combined Stratosphere-Troposphere CTM}

The GMI CTM combines a tropospheric $\mathrm{O}_{3}-\mathrm{NO}_{\mathrm{x}}-$ hydrocarbon mechanism (Bey et al., 2001) with a 
stratospheric mechanism (Douglass et al., 2004). It includes 117 species, 322 chemical reactions, and 81 photolysis reactions. Aerosols, including sulfate, dust, sea-salt, organic carbon, and black carbon, obtained from the Goddard Chemistry Aerosol Radiation and Transport (GOCART) model for 2001 (Chin et al., 2002), are input into the CTM. While halogen chemistry is important in simulating spring ozone depletion in the LT in the Arctic (e.g. Oltmans, 1981; Bottenheim et al., 1986), it is not included in the current GMI model. However, we do not expect this to affect the results of this study. The advection scheme is described by Lin and Rood (1996). The convective transport scheme, described in Rasch et al. (1997), incorporates a shallow convection algorithm (Hack, 1994) with a deep convection scheme (Zhang and McFarlane, 1995). Photolysis rates are computed with the optimized FastJx scheme (Bian and Prather, 2002). Fossil fuel emissions are described in Bey et al. (2001) and Duncan et al. (2007b). Biofuel and biomass burning emissions are from Yevich and Logan (2003) and Duncan et al. (2003), respectively. A detailed description of the GMI CTM can be found in Duncan et al. (2007a).

Here we include results from a GMI full chemistry simulation driven by five years of meteorological fields from the Goddard Modeling and Assimilation Office (GMAO) GEOS4 general circulation model (GEOS-4 GCM) (Bloom et al., 2005). The five-year meteorological fields are forced with observed sea surface temperatures between 1994 and 1998, but otherwise do not correspond to any specific year. The horizontal resolution of the simulation is $2^{\circ}$ latitude by $2.5^{\circ}$ longitude. The original meteorological fields have 55 layers extending from the surface to $0.01 \mathrm{hPa}$, which have been regridded to 42 layers. There are 20 layers from the surface to the lower stratosphere (LS, $>60 \mathrm{hPa}$ ) with about $1 \mathrm{~km}$ resolution near the tropopause. The tropopause is defined using a combination of temperature profiles and potential vorticity as the highest thermal tropopause (defined by temperature lapse rate) below 3 PVU. The surface and upper level meteorological fields are updated every 3 and $6 \mathrm{~h}$, respectively. Advection and chemistry are computed every 30 minutes and 30min output are accumulated to calculate monthly averages.

CTM simulations using the GEOS-4 GCM meteorological fields produce a realistic mean Brewer-Dobson circulation with mean age of stratospheric air that is similar to observations (Strahan and Douglass, 2004; Douglass et al., 2008). This is important for this study because the magnitude and seasonal cycle of STE is strongly tied to the Brewer-Dobson circulation through the overworld wave driving (Holton et al., 1995). Olsen et al. (2004) showed that the exchange of mass and ozone between the stratosphere and troposphere in a CTM simulation driven with the GEOS-4 GCM meteorological fields compares well with estimates derived from observations. In comparison, a CTM simulation using an older version of the GEOS-4 Data Assimilation System (GEOS4 DAS) produces a "fast" Brewer-Dobson circulation and "young" age of air as compared to the observations (Dou- glass et al., 2008). Although the Brewer-Dobson circulation and age of air are much improved using time-averaged meteorological fields from a more recent version of the GEOS-4 DAS (Pawson et al., 2007), a GMI full chemistry simulation using the GEOS-4 DAS meteorological fields clearly shows the model's inadequacy in correctly simulating the amplitude and phase of the seasonal cycle of $\mathrm{O}_{3}, \mathrm{HNO}_{3}$ and CFCs in the UT. The simulated STE-related seasonal cycle of these trace gases peaks 1-2 months early and the amplitude is significantly smaller than the observations. Hence, for this study, we focus on the results from the GMI simulation driven by the GEOS-4 GCM meteorological fields.

To address the proposed tasks of this study, we included a stratospheric ozone diagnostic $\left(\mathrm{O}_{3} \mathrm{ST}\right)$ and a set of dynamic tracers in our simulation using a two-year subset of the meteorological fields from 1996-1997.

\section{i) GMI stratospheric ozone tracer}

We used $\mathrm{O}_{3} \mathrm{ST}$ to separate ozone from the stratosphere from that produced in the troposphere. $\mathrm{O}_{3}$ and $\mathrm{O}_{3} \mathrm{ST}$ are transported separately in the GMI CTM. Above the tropopause, $\mathrm{O}_{3} \mathrm{ST}$ is the same as $\mathrm{O}_{3}$. In the troposphere, $\mathrm{O}_{3} \mathrm{ST}$ is treated like $\mathrm{O}_{3}$ but without any tropospheric production. $\mathrm{O}_{3} \mathrm{ST}$ is destroyed by photolysis, by the reaction with $\mathrm{OH}$ and $\mathrm{HO}_{2}$, and surface deposition. The difference between $\mathrm{O}_{3}$ and $\mathrm{O}_{3} \mathrm{ST}\left(\mathrm{O}_{3}\right.$ minus $\left.\mathrm{O}_{3} \mathrm{ST}\right)$ corresponds to ozone produced in the troposphere, $\mathrm{O}_{3} \mathrm{TR}$. Our $\mathrm{O}_{3} \mathrm{ST}$ is a good first-order proxy for the influence of STE on tropospheric $\mathrm{O}_{3}$.

\section{ii) GMI dynamic tracers}

During downward transport to the LT, which occurs over several months, the removal mechanisms and overall lifetime of a trace gas can have a substantial impact on its seasonality. We designed a set of dynamic tracers with varying lifetimes in the GMI CTM simulation to track STT and determine the impact of lifetime on STE-related seasonality. The set includes four tracers with lifetimes of one month (DT 1 -month), two months $\left(\mathrm{DT}_{2-\text { month }}\right)$, four months $\left(\mathrm{DT}_{4-\text { month }}\right)$, and six months $\left(\mathrm{DT}_{6-\text { month }}\right)$. For the timescale of tropospheric transport, $\mathrm{DT}_{1-\text { month }}$ serves as a good proxy for short-lived radioactive tracers, e.g. ${ }^{90} \mathrm{Sr}$ and ${ }^{7} \mathrm{Be}$, and $\mathrm{DT}_{6 \text {-month }}$ is representative, for our purposes, of long-lived tracers, e.g. CFCs. The combination of tracers with varying lifetimes from 1-6 months offers valuable information on how trace gases with intermediate lifetimes, e.g. $\mathrm{O}_{3}$ (lifetime from a few days to $\sim 100$ days depending on altitude, latitude and season, Seinfeld and Pandis, 1997) and $\mathrm{HCl}$ (lifetime of a few weeks, Marcy et al. 2004), would behave during STT. At each time step, the mixing ratios of the dynamic tracers above the tropopause are set to a prescribed annual cycle. The prescribed annual cycle is defined by first averaging CFC- 12 in the LS between $70-90^{\circ} \mathrm{N}$ and then normalizing the averaged annual cycle to yield an 
annual average of $100 \mathrm{ppbv}$ and peak-to-trough amplitude of $100 \mathrm{ppbv}$. The prescribed annual cycle maximizes in April to mimic the seasonal variation of CFC-12 in the extratropical LS for easy comparison. The dynamic tracers are transported into the troposphere and removed with an exponential decay rate of $1 / \tau$ ( $\tau$ is the lifetime of the tracer).

To better understand the process of STE and its governing factors, we use a set of sub-tracers with a lifetime of six months each to track STT at seven 10-degree latitude bands between $20^{\circ} \mathrm{N}$ and $90^{\circ} \mathrm{N}$. As described in the preceding paragraph, each sub-tracer is fixed with the same annual cycle in the above-tropopause region at the latitude where it descends across the tropopause and is set to zero at all other latitudes above the tropopause. For example, the tracer to track STT at $30-40^{\circ} \mathrm{N}$ is set to prescribed monthly values above the tropopause between $30-40^{\circ} \mathrm{N}$ and zero everywhere else above the tropopause. The sub-tracers are transported separately in the troposphere and their sum equals $\mathrm{DT}_{6-\text { month }}$.

We also use a dynamic tracer $\left(\mathrm{DT}_{\mathrm{fix}}\right)$ that has a lifetime of six months and a fixed constant mixing ratio of $100 \mathrm{ppbv}$ throughout the year above the tropopause. The combination of $\mathrm{DT}_{6-\text { month }}$ and $\mathrm{DT}_{\text {fix }}$ quantifies the relative contribution of STE to a trace gas in the troposphere due to the seasonal variations in the tropopause height and STE flux versus the seasonal variations of concentrations of that trace gas in the LS.

\subsection{GEOS CCM CFC-12 simulation}

We include in this study the simulated $\mathrm{CCl}_{2} \mathrm{~F}_{2}$ (CFC-12) between 1995 and 2004 from the Goddard Space Flight Center (GSFC) GEOS Chemistry Climate Model (GEOS CCM) Version 1 (Stolarski et al., 2006; Pawson et al., 2008). The GEOS CCM couples the GEOS-4 GCM (Bloom et al., 2005) with a stratospheric chemistry module (Douglass et al., 2004). CFC-12 is emitted at the surface and destroyed photolytically in the stratosphere. In the troposphere, loss of CFC- 12 is negligible and CFC- 12 can be used as a tracer for air mass transport. In addition to CFC-12, we include a tagged tracer, CFC-12S, to track stratospheric influence in the troposphere. CFC-12S is defined as the concentration of aged emissions that accumulates in the atmosphere and has at some time been in contact with the stratosphere. Above the tropopause, total CFC-12 equals CFC-12S. In the troposphere, CFC-12S represents the aged component of total CFC-12 that is transported from the stratosphere to the troposphere, in contrast to recent emissions released at the surface. The deviation of CFC-12S from its annual mean concentration in the troposphere provides information on STT flux. A detailed description of the CFC-12 simulation is included in Liang et al. (2008).

\section{Model validation using observations}

In this section, we evaluate the simulated $\mathrm{CFC}-12$, nitric acid $\left(\mathrm{HNO}_{3}\right)$, and $\mathrm{O}_{3}$ with observations in the LS and troposphere.

\subsection{A summary of observations}

\section{Ozonesondes}

We use 10 years of ozonesonde data at three Arctic stations: Alert $\left(82.3^{\circ} \mathrm{N}, 62.3^{\circ} \mathrm{W}\right)$, Eureka $\left(80.0^{\circ} \mathrm{N}, 86.0^{\circ} \mathrm{W}\right)$, and Resolute $\left(75.0^{\circ} \mathrm{N}, 95.0^{\circ} \mathrm{W}\right)$. This study includes sounding data taken from 1995 to 2005 with a weekly to bi-weekly launch schedule. The ozonesondes were launched by the Meteorological Service of Canada and are publicly archived at the World Ozone and UV Data Centre (http://www.woudc.org). From this network, we calculate monthly mean profiles of ozone mixing ratio and pressure for each station at a vertical resolution of $0.5 \mathrm{~km}$.

\section{ACE-FTS measurements}

We use space-borne measurement of CFC-12, $\mathrm{HNO}_{3}$, and $\mathrm{O}_{3}$ from the Atmospheric Chemistry Experiment (ACE) (Bernath et al., 2005). The ACE instrument on the Canadian satellite SCISAT-1 was launched on 12 August 2003 and has been fully operational since January 2004. One primary scientific goal for ACE is to understand the chemical and dynamical processes that control the distribution of $\mathrm{O}_{3}$ in the stratosphere and UT, particularly in the Arctic. The satellite has a $74^{\circ}$ inclined orbit at an altitude of $650 \mathrm{~km}$, providing up to 15 sunrise and 15 sunset solar occultations per day. This orbit provides spatial coverage in the tropics, midlatitudes and polar region, with a sampling frequency that is highest in the Arctic and Antarctic. The principal SCISAT-1 is a high resolution $\left(0.02 \mathrm{~cm}^{-1}\right)$ infrared Fourier transform spectrometer (ACE-FTS) operating from $750-4400 \mathrm{~cm}^{-1}$. The ACE-FTS provides profiles of atmospheric constituents with an altitude resolution of $\sim 4 \mathrm{~km}$. A second instrument, Measurement of Aerosol Extinction in the Stratosphere and Troposphere Retrieved by Occultation (MAESTRO), is a dual optical spectrophotometer that covers the $285-1030 \mathrm{~nm}$ spectral region. The MAESTRO measures ozone, nitrogen oxide, and aerosol/cloud extinction at a vertical resolution of $1-2 \mathrm{~km}$.

\section{MkIV balloon measurements}

We also use six balloon measurements of CFC-12, $\mathrm{HNO}_{3}$, and $\mathrm{O}_{3}$ from the Jet Propulsion Laboratory (JPL) MkIV balloon-borne interferometer, which is a high-resolution Fourier Transform Infrared Spectrometer (Toon et al., 2001). Four of the six balloon measurements were launched in Esrange, Sweden, in December 1999, March 2000, December 


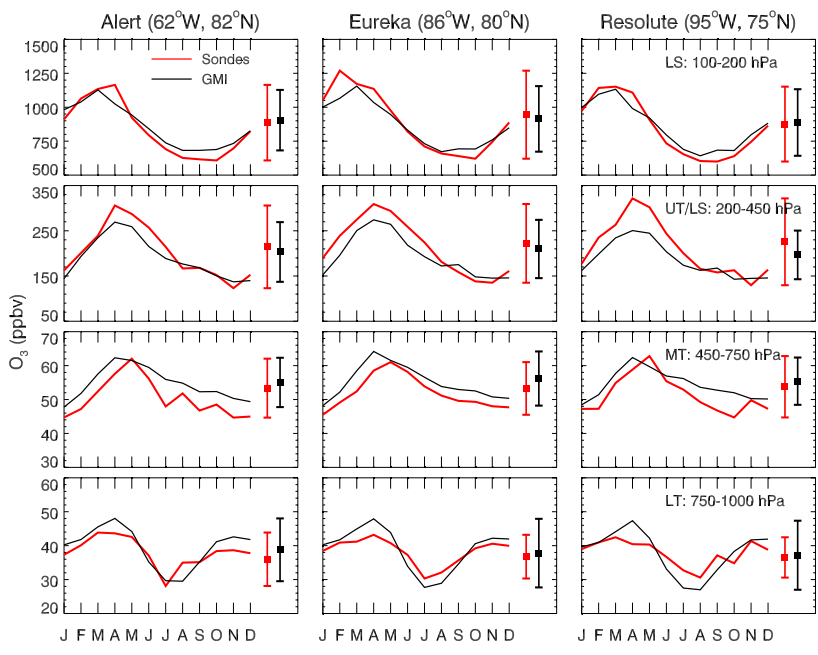

Fig. 1. Seasonal cycle of ozone from ozonesondes (red) and model (black) in the LS and troposphere at Alert, Eureka, and Resolute. The filled squares and error bars on the right of each panel indicate the annual average mixing ratio and amplitude of annual cycle (maximum-minimum).

2000, and April 2003. Two were launched in Fairbanks, Alaska, in May 1997 and July 1997. The balloon measurements were reported at $1 \mathrm{~km}$ vertical interval and extend from the UT/LS to $\sim 35 \mathrm{~km}$ altitude level.

\subsection{Comparison of simulations and observations}

Figure 1 shows the ten-year monthly averaged ozonesonde data at three Canadian polar sites, Alert, Eureka, and Resolute. Ozone at these sites shows a maximum in FebruaryMarch and a late summer/early fall (August-October) minimum in the LS (Fig. 1, top panels). In the free troposphere, $\mathrm{O}_{3}$ shows a prominent April-May maximum and gradually decreases to a fall/winter (October-January) minimum (Fig. 1, 2nd and 3rd rows). In the LT, maximum $\mathrm{O}_{3}$ appears in spring (March-April) and minimum in summer (July-August) (Fig. 1, bottom panels). The simulated $\mathrm{O}_{3}$ agrees well with the ozonesonde data. The difference between the simulated and observed annual average concentration ranges from $-12.8 \%$ to $5.5 \%$ and the correlation of determination $\left(\mathrm{r}^{2}\right)$ of the monthly mean mixing ratios range from $0.83-0.95$ at all levels. Of particular importance to the STE process, the model reproduces well the observed phase and amplitude of the seasonal cycle in the LS. In the free troposphere, the model simulates well the phase of the seasonal cycle but underestimates the amplitude by $\sim 30 \%$ in the UT.

Figure 2 shows the comparison of the simulated CFC$12, \mathrm{HNO}_{3}$ and $\mathrm{O}_{3}$ with the ACE and MkIV measurements. In the LS and UT, CFC-12 shows a seasonal minimum while $\mathrm{HNO}_{3}$ and $\mathrm{O}_{3}$ show a maximum in late winter/spring (February-April) (Fig. 2) due to wintertime downwelling associated with the Brewer-Dobson circulation, which brings
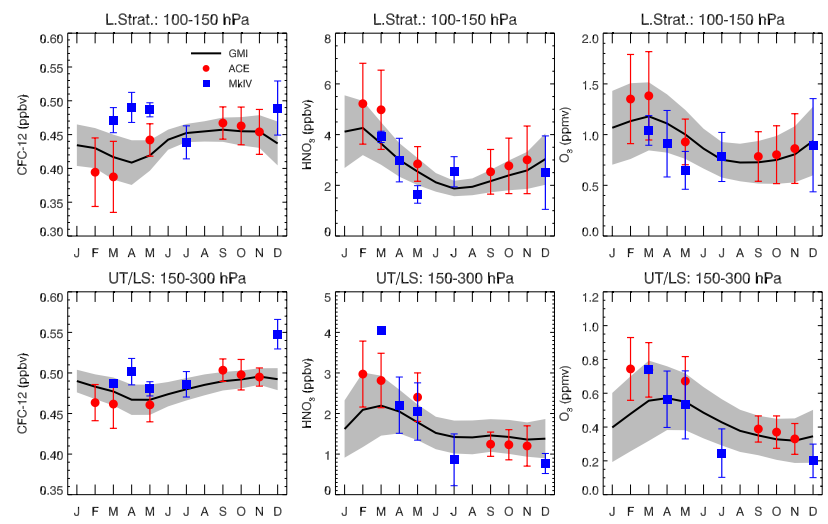

Fig. 2. Annual cycle of observed and simulated (black lines with one standard deviation shown in gray shading) $\mathrm{CFC}-12, \mathrm{HNO}_{3}$, and ozone in the stratosphere and near-tropopause region in the Arctic $\left(70-90^{\circ} \mathrm{N}\right)$. ACE observations and MkIV balloon measurements are plotted as red circles and blue squares, respectively. Vertical error bars indicate one standard deviation.

high-altitude air that is CFC-depleted and rich in $\mathrm{HNO}_{3}$ and $\mathrm{O}_{3}$ (Nevison et al., 2004; Liang et al., 2008). The simulated $\mathrm{CFC}-12, \mathrm{HNO}_{3}$, and $\mathrm{O}_{3}$ agree relatively well with the ACE measurements, but to a lesser degree with the MkIV balloon measurements. Note that $\mathrm{HNO}_{3} / \mathrm{O}_{3}$ (CFC-12) concentrations increase (decrease) rapidly with altitude in the UT/LS region. Therefore the comparison between model and observation is sensitive to the sampling location. Part of the differences between the model and observation is by this limited sampling. The ACE measurements are available at limited geographical locations/altitudes and the MkIV measurements only include six daily profiles (compared to the model results that are averaged for 5 years and over the entire Arctic UT/LS). However, in the Arctic UT/LS region, where observations are limited, these measurements offer valuable information for model validation. These comparisons, in addition to that with the ozonesonde, indicate that the model presents a reasonable representation of the chemistry and dynamics that regulates the concentrations of $\mathrm{CFC}-12, \mathrm{HNO}_{3}$, and $\mathrm{O}_{3}$ in the Arctic UT/LS.

Our simulated CFC-12 compares well with surface measurements at multiple observation sites from the Advanced Global Atmospheric Gases Experiment (AGAGE) (Prinn et al., 2000) and National Oceanic and Atmospheric Administration - Global Monitoring Division (NOAA-GMD) (Montzka et al., 1999; Thompson et al., 2004) throughout the globe. The difference between the simulated CFC-12 and the observations is less than $2 \%$. A detailed comparison is presented in Liang et al. (2008). Of particular relevance to this study, the model reproduces well the amplitude and phase of the seasonal cycle of CFC-12, which is predominantly driven by STT after the mid-1990's (Liang et al., 2008). The fact that our simulated seasonal minimum in the lower stratosphere and at the surface (the minimum at the surface lags 

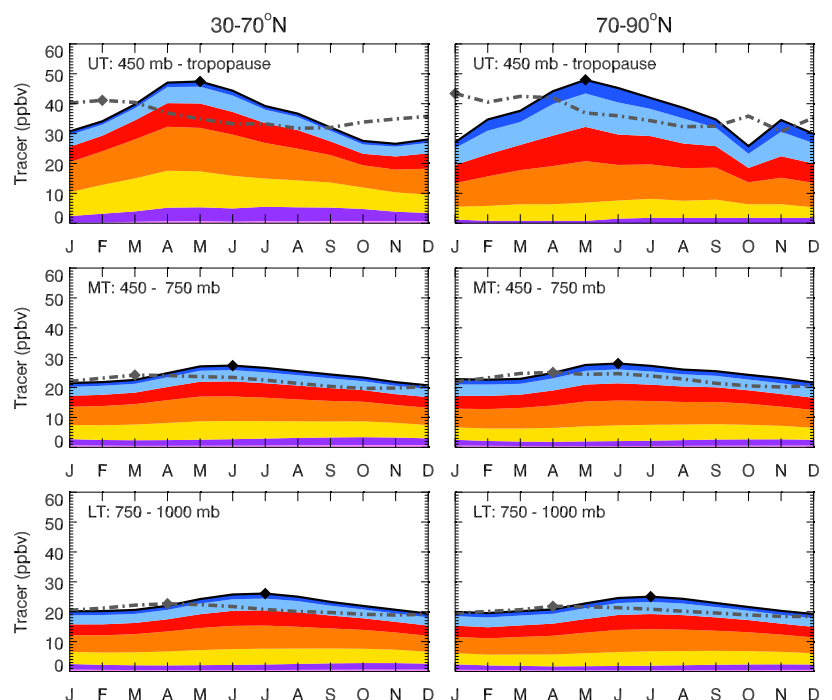

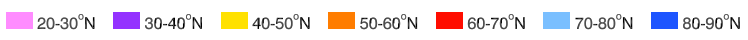

Fig. 3. Monthly mean contribution of STE from seven $10^{\circ}$-latitude bands from $20-90^{\circ} \mathrm{N}$ to $\mathrm{DT}_{6-\text { month }}$ in the $\mathrm{NH}$ troposphere from $30-70^{\circ} \mathrm{N}$ (left panels) and $70-90^{\circ} \mathrm{N}$ (right panels). Each shade corresponds to the contribution from one $10^{\circ}$-latitude band and the stacked sum is the total mixing ratio of $\mathrm{DT}_{6-\text { month }}$ as outlined by the black solid line. The gray dash-dotted line shows $\mathrm{DT}_{\mathrm{fix}}$. The diamond symbols mark the seasonal maximum concentration.

the minimum in the LS by 3 months) agrees well with the observations suggests a realistic representation of STE/STT in the GEOS-4 GCM meteorological fields, which occurs slowly during a 3-month period. This provides a crucial observational constraint on model-simulated stratosphere-totroposphere transport time.

\section{Stratosphere-to-troposphere transport}

In this section we examine the annual cycles of the dynamic tracers and CFC-12 to understand the stratospheric injection of trace gases and their subsequent transport within the troposphere.

\subsection{STT: Timescale and mechanism}

Figure 3 shows the monthly mean concentration of $\mathrm{DT}_{6-\text { month }}$ in the northern extra-tropical troposphere. The mixing ratio of $\mathrm{DT}_{6-\text { month }}$ in the UT is significantly lower (annual average $\sim 36.5 \mathrm{ppbv}$ between $30-90^{\circ} \mathrm{N}$ ) with a smaller amplitude of the annual cycle (22.5 ppbv) as compared to the prescribed annual cycle above the tropopause (annual average $=100$ ppbv, amplitude $=100$ ppbv) (Fig. 3, top panels). The seasonal maximum is delayed from April to May, indicating an average transport time of one month across the tropopause. This is consistent with the findings from Haynes et al. (1991) and Stohl (2001). They suggested that while stratospheric intrusions are commonly associated with synoptic-scale tropopause folding events, on the very large scale, it is the slow transport processes that control the net STE flux as determined by the downward control principal. As air of stratospheric origin travels downward, the concentration of $\mathrm{DT}_{6-\text { month }}$ continues to decrease to $24 \mathrm{ppbv}$ in the middle troposphere (MT) (Fig. 3, middle panels) and $22 \mathrm{ppbv}$ in the lower troposphere (LT) (Fig. 3, bottom panels). The attenuation in the annual amplitude is more significant, a factor of 4 (5.8-6.6 ppbv). The maximum con-

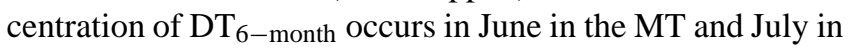
the LT. This suggests an average downward propagation time of one month from the UT to the MT and an additional one to the LT. Our deduced downward transport time is similar to that shown in three previous studies, James et al. (2003), Stohl et al. (2003), and Stohl (2006). James et al. (2003) and Stohl et al. (2003) showed that STT tracers $(\mathrm{PV}>2)$ with an age of 0-20 days account for only $18.3 \%$ of air in the troposphere, while tracers with age 20-90 days and $>90$ days account for $37.5 \%$ and $44.1 \%$, respectively. Mixing ratios of STT tracers with young age of air (0-20 days) maximize at $\sim 5-8 \mathrm{~km}$ in the Arctic troposphere, and those with age 20-90 days and $>90$ days maximize at $3 \mathrm{~km}$ and surface, respectively. This implies vertical transport times of $\sim 1$ month to the upper troposphere and $\geq 3$ months to the surface. Stohl (2006) showed that the average transport time in the lower troposphere in the Arctic since a particle left the stratosphere is on the order of 100 days.

We decompose $\mathrm{DT}_{6-\text { month }}$ into contributions from STE at seven $10^{\circ}$ latitude bands. STE occurs predominantly between $40^{\circ} \mathrm{N}$ to $80^{\circ} \mathrm{N}(>95 \%)$. The strongest injection is in the $50-60^{\circ} \mathrm{N}$ band, contributing $30 \%$ of total stratospheric air in the $\mathrm{NH}$ extra-tropical troposphere. This agrees well with the results from Hsu et al. (2005) who found stratospheric $\mathrm{O}_{3}$ influx occurred predominantly in the midlatitudes during spring and summer while the high latitudes was not a significant region of STE.

There is no significant difference in the concentration, amplitude, and latitudinal composition of $\mathrm{DT}_{6-\text { month }}$ between the mid and high latitudes because of efficient mixing in the troposphere (Fig. 3). This mixing occurs mainly via largescale advection and transport around high and low pressure systems (Shipham et al., 1992). Of particular importance is the transport associated with the air streams of extra-tropical cyclones, the most important exchange mechanism in the extra-tropics (Cotton et al., 1995), which enable rapid exchange of air in the vertical and horizontal. Following STE, the air of stratospheric origin is transported downward and equatorward in the dry airstreams (DA) in the extra-tropical cyclones (Browning et al., 1997). The stratospheric air is recirculated back to the higher latitudes in the cold conveyor belt (CCB) and the warm conveyor belt (WCB) in cyclones. Because these air streams in extra-tropical cyclones show low coherency, the air of stratospheric origin experiences rapid filamentation and mixes with the background 

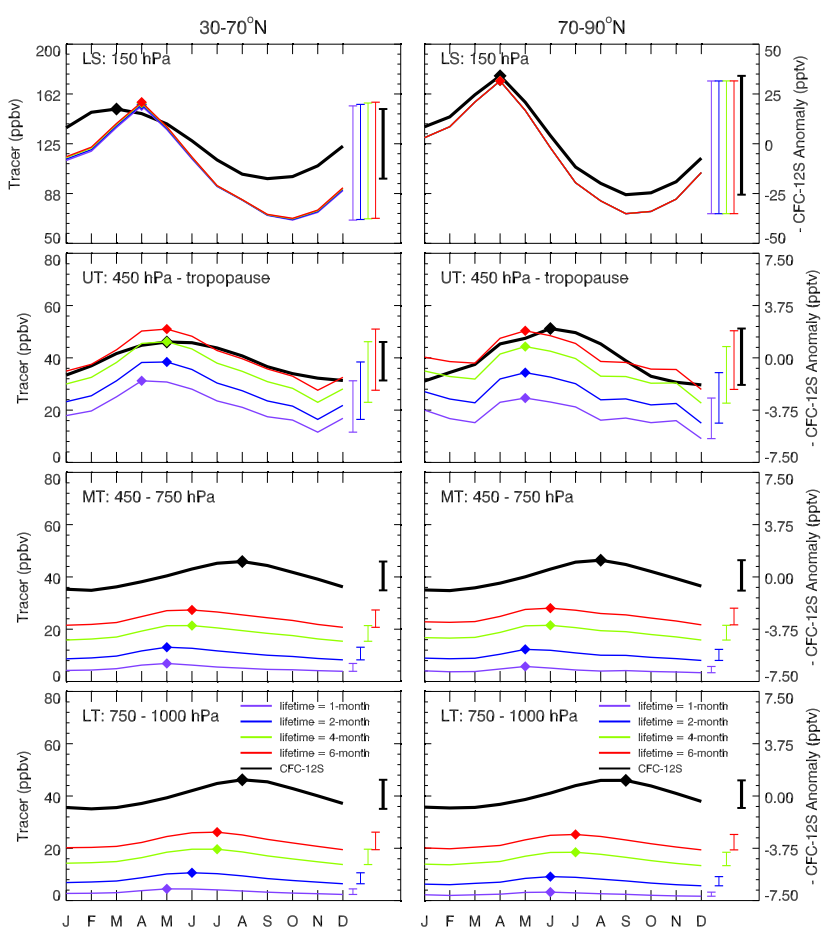

Fig. 4. Seasonal cycle of the dynamic tracers (color lines) in the $\mathrm{NH}$ troposphere. For easy comparison with the seasonal peak of the dynamic tracers, the opposite sign of the stratospheric CFC-12 tracer anomalies (-CFC-12S anomaly) is plotted (black lines). The diamond symbols mark the seasonal maximum concentration. Vertical bars on the right of each panel show the amplitude of seasonal variation.

tropospheric air during transport (Stohl, 2001). A more detailed explanation of transport of air between high and low latitudes and different layers of the atmosphere associated with the air streams in the cyclones can be found in Cooper et al. (2000) and Stohl (2001).

The flux of a trace gas across the tropopause is determined by the convolution of air mass flux and its concentration in the LS (Olsen et al, 2004). The comparison between $\mathrm{DT}_{\text {fix }}$, with constant mixing ratio above the tropopause, and $\mathrm{DT}_{6-\text { month }}$, with a specified annual cycle above the tropopause, segregates the contribution from seasonal changes in mass flux (Fig. 4). In the mid-latitude UT, the maximum of $\mathrm{DT}_{\text {fix }}$ occurs in February (Fig.. 4, 2nd row) as a result of maximum cross-tropopause flux at this time (Olsen et al., 2004). This maximum appears three months earlier than that of $\mathrm{DT}_{6-\text { month }}$. The maximum of $\mathrm{DT}_{\mathrm{fix}}$, with the same lifetime as $\mathrm{DT}_{6 \text {-month }}$, occurs one month later (March) in the MT (Fig. 4, 3rd row) and two months later (April) in the LT (Fig. 4, bottom row).

The phase difference between $\mathrm{DT}_{\text {fix }}$ and $\mathrm{DT}_{6-\text { month }}$ suggests that, for a CFC-like tracer that is significantly influenced by the Brewer-Dobson circulation, its annual cycle in the troposphere due to STE is dominated by the seasonal change in its concentration in the LS. DT $\mathrm{T}_{\mathrm{fix}}$ in the polar troposphere is not particularly different from that in the midlatitudes, but its seasonal maximum is delayed by one month. The one month delay is due to two factors: i) mass transport across the tropopause in the high latitudes (March) occurs one month later than in the mid latitudes (February), ii) secondly, it takes about one month to transport stratospheric intrusions from the mid to high latitudes.

\subsection{Impact of lifetime}

The lifetime of a trace gas exerts a significant impact on its concentration and the timing of its seasonal maximum/minimum during STT. Figure 4 shows the annual cycle of four STE tracers with various fixed lifetimes in the troposphere. Though initialized with the same concentration in the stratosphere, the tracers exhibit a different seasonality in the troposphere. The seasonal variation of downward transport of $\mathrm{DT}_{4-\text { month }}$ is similar to that of $\mathrm{DT}_{6-\text { month }}$ with comparable amplitudes and coincident seasonal maxima, but smaller concentrations (20-25\%). $\mathrm{DT}_{2-\text { month }}$ shows a coincident seasonal maximum (May) and similar amplitude in

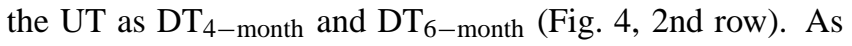
the tracer continues to descend into the MT and LT, its amplitude is only $2 / 3$ of that of $\mathrm{DT}_{6-\text { month }}$ and its maximum occurs one month earlier (May in the MT and June in the LT) (Fig. 4, two bottom rows). Due to its fastest destruction rate (short lifetime), $\mathrm{DT}_{1-\text { month }}$ has the lowest concentration and the smallest annual amplitude as compared to the other three tracers. Its seasonal maximum occurs in May throughout the troposphere, only one month behind the seasonal maximum above the tropopause.

The contrast between the idealized tracers shows that during STT, tracers that have a shorter lifetime display lower concentrations, smaller amplitudes, and earlier seasonal maxima. The difference between tracers is most apparent in the mid-latitude LT. This explains why short-lived STE tracers like ${ }^{7} \mathrm{Be}$ and ${ }^{90} \mathrm{Sr}$ have a spring maximum and STE tracers like CFC-12 that are inert in the troposphere show maximum stratospheric influence in late summer. In addition, this implies that while many trace gases that are influenced by STE, e.g., $\mathrm{O}_{3}, \mathrm{CFCs},{ }^{7} \mathrm{Be}, \mathrm{HCl}, \mathrm{HNO}_{3}$, are highly correlated in a stratospheric intrusion event (e.g. Marcy et al., 2004; Liang et al., 2007), their monthly-averaged influences in the troposphere can be significantly different due to chemical removal and scavenging.

\subsection{Impact of lower stratospheric variation}

The STT-driven seasonal cycle of a trace gas in the troposphere is also impacted by the latitudinal differences in its seasonal cycle in the LS. This is demonstrated by the differences in the seasonality between CFC-12 and the idealized tracers (Fig. 4). In contrast to the idealized tracers forced with the same seasonal cycle in the NH stratosphere, the 


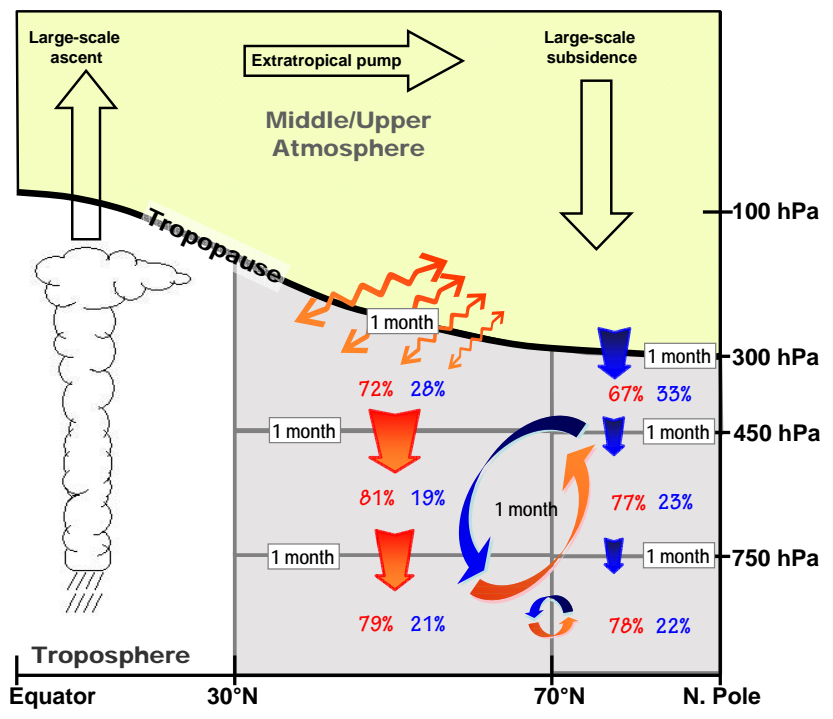

Fig. 5. A schematic diagram of STE and subsequent transport into the lower troposphere, augmented based on Fig. 3 in Holton et al. (1995). The wavy orange arrows across the tropopause represent quasi-horizontal STE in the mid-latitudes $\left(30-70^{\circ} \mathrm{N}\right)$ by eddy motions. The blue arrow across the polar tropopause denotes STE in the high latitudes mostly via slow diabatic descending. The orange and blue arrows in the troposphere illustrate the subsequent transport of stratospheric air with the approximate length of transport time from one region to the next denoted by " 1 month" labels. Descent of air from the tropopause to the lower surface takes a total of 3 months. After entering the troposphere, air of stratospheric origin also experiences efficient exchange between the mid and high latitudes large scale advection and transport in high pressure systems and extra-tropical cyclones. The timescale of exchange between the mid latitudes and the polar region is on the order of one month. The percents indicate the relative composition of stratospheric influence (red for stratospheric air via STE between $30-70^{\circ} \mathrm{N}$ and blue for that occur $>70^{\circ} \mathrm{N}$ ) in different regions in the $\mathrm{NH}$ mid-latitude and polar troposphere. Stratospheric influence in the NH troposphere is dominated by STE in the mid-latitudes, accounting for $67-81 \%$ of total stratospheric air.

seasonal cycle of CFC-12 is different in the mid-latitude LS and the polar LS. The amplitude of the seasonal cycle of CFC-12 in the polar LS is twice that in the mid-latitudes and the seasonal minimum occurs one month later. This implies that while the quasi-horizontal transport along isentropes into the mid-latitude UT/LS region is more efficient and more rapid, the vertical downward penetration associated with the Brewer-Dobson circulation is strongest near the pole and plays a dominant role in determining the seasonal cycle of CFC-12 in the LS and the troposphere. In particular, the timing of the seasonal minimum of CFC-12 in the troposphere is dominated by STE in the high latitudes. The high latitude stratospheric influx is first transported to the mid-latitudes in the dry intrusions behind the cold fronts in the mid-latitude cyclones and then recirculates back to the polar region. Daily maps of CFC-12S clearly show this recirculation between the mid and high latitudes (not shown). While CFC-12S and $\mathrm{DT}_{6-\text { month }}$ start with the seasonal peak of (minimum of CFC-12S and maximum of $\mathrm{DT}_{6-\text { month }}$ ) in the LS and take the same transport route, the minimum of CFC-12S in the troposphere occurs 1-2 month later than the

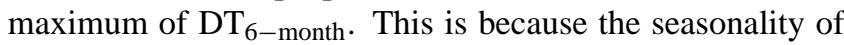
CFC-12S is predominantly determined by the transport of STE flux in the high latitudes and this recirculation of the high-latitude influx results in a delay in its seasonal minimum.

\subsection{A schematic summary}

We summarize the timescale of STT and the relative contribution from STE in the mid and high latitudes in a schematic diagram (Fig. 5), an augmented version of Fig. 3 from Holton et al. (1995). STE can occur adiabatically along isentropes or diabatically (e.g. Dethof et al. 2000; Yang and Tung, 1996; Schoeberl et al., 2004; Olsen et al., 2004), through a variety of synoptic-scale eddy exchange activities, including tropopause folds and upper tropospheric troughs (Shapiro et al., 1987; Holton et al., 1995), or with small-scale processes or with global-scale diabatic ascent or descent (Holton et al., 1995). Much of the episodic STE is in the form of shallow and transient intrusions, with more than $90 \%$ of the crosstropopause flow returns to the stratosphere within a few hours (James et al., 2003). Rapid deep STT that penetrates into the lower troposphere does not occur frequently (James et al., 2003). On long-term global scale, STE and the subsequent transport in the troposphere, particularly in the Arctic, occur via downward transport across the isentropic surfaces, which requires diabatic cooling. Using the propagation of the seasonal maximum/minimum of CFC-12 and dynamic tracers, we found that diabatic descent from the LS to the surface is slow and occurs over several months. The average transport time from the LS to the UT in the extra-tropics is one month. Subsequent transport of stratospheric air to the LT takes two months, one month from the UT to the MT and an additional month from the MT to the LT. STE occurs predominantly in the mid-latitudes, with the stratospheric injection between $30-70^{\circ} \mathrm{N}$ accounting for $67-81 \%$ of the air of stratospheric origin in the free troposphere and the injection between $70-90^{\circ} \mathrm{N}$ for the remaining $19-33 \%$. This is because quasi-isentropic horizontal mixing in the mid-latitude UT/LS is more efficient and significantly faster than slow vertical diabatic descent near the pole. After entering the troposphere, the air of stratospheric origin also experiences efficient exchange between the mid and the high latitudes via large-scale advection, transport by high pressure systems and extra-tropical cyclones. The timescale of exchange between the mid latitudes and the polar region is on the order of one month. 


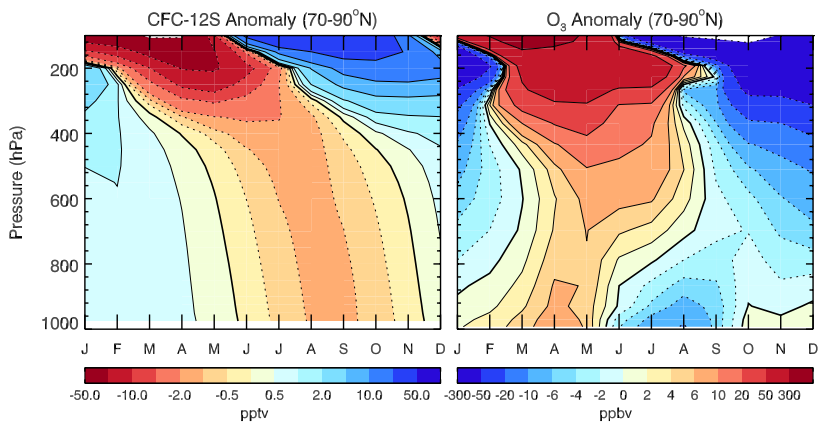

Fig. 6. Seasonal cycle of monthly mean stratospheric CFC-12 tagged tracer (CFC-12S) and ozone anomaly averaged between $180^{\circ} \mathrm{W}-180^{\circ} \mathrm{E}$ and $70-90^{\circ} \mathrm{N}$. CFC- $12 \mathrm{~S}$ is a tagged component of CFC-12 used to track the downward transport from the stratosphere to the troposphere.

\section{Stratospheric contribution to ozone in the Arctic tro- posphere}

\subsection{Direct transport of stratospheric ozone}

We contrast the seasonal cycle of $\mathrm{O}_{3}$ and CFC-12 in the Arctic troposphere to determine the difference in their STT. Compared with CFC-12, which is inert in the troposphere, the downward transport of stratospheric $\mathrm{O}_{3}$ is clearly impacted by photochemical destruction (Fig. 6). The downward propagation of the seasonal cycle of $\mathrm{O}_{3}$ is similar to that of CFC-12 in the UT. However, the maximum concentration of $\mathrm{O}_{3}$ appears 1-2 months earlier than the CFC-12 minimum in the MT, due to a shorter lifetime particularly in summer. In the LT, $\mathrm{O}_{3}$ has a spring maximum and a summer minimum as regulated by photochemical production and loss.

We further quantify the contribution from STE and tropospheric in situ production to $\mathrm{O}_{3}$ and its seasonal cycle in the troposphere (Fig. 7). The largest source of $\mathrm{O}_{3}$ in the UT is the transport of $\mathrm{O}_{3}$ from the LS. Stratospheric $\mathrm{O}_{3}\left(\mathrm{O}_{3} \mathrm{ST}\right)$, on average, contributes $89.6 \mathrm{ppbv}, 77.6 \%$ of total $\mathrm{O}_{3}$ (115.4 ppbv), with a broad spring maximum from March to May. The stratospheric contribution decreases significantly in the MT (13.0 ppbv, 24.5\%) and the LT (7.8 ppbv, 19.9\%), with a very weak seasonal cycle (amplitude $\sim 1-2$ ppbv) that peaks in March-April. The diminished seasonal cycle is a result of a coincident increase of stratospheric input from spring to summer and a decrease in the $\mathrm{O}_{3}$ lifetime from 4 months in March to $<1$ month in July-August (not shown). In situ photochemical production accounts for $75-80 \%$ of $\mathrm{O}_{3}$ at pressures higher than $450 \mathrm{hPa}$ and plays a key role in determining the seasonal cycle of $\mathrm{O}_{3}$ in the MT and LT. Interestingly, $\mathrm{O}_{3}$ produced in the troposphere $\left(\mathrm{O}_{3} \mathrm{TR}\right)$ shows a different seasonality at various altitudes. $\mathrm{O}_{3}$ TR in the UT gradually increases from $\sim 15 \mathrm{ppbv}$ in March to peak values of $\sim 40 \mathrm{ppbv}$ in June-July. $\mathrm{O}_{3}$ TR in the MT shows a broader peak which starts in May and extends from late spring to summer. In
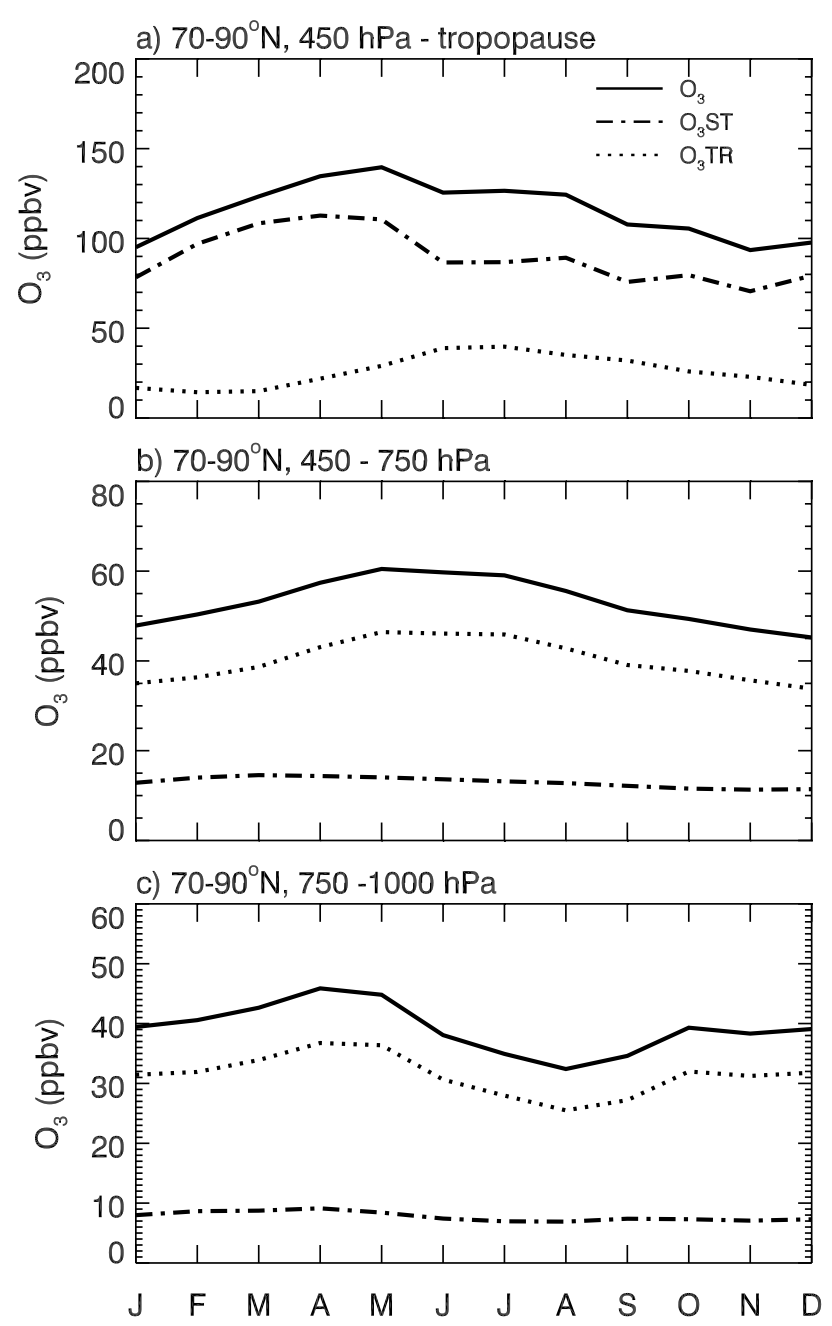

Fig. 7. Seasonal cycle of simulated monthly mean ozone (solid lines), stratospheric ozone contribution (dash-dotted lines) and their difference (tropospheric ozone, dotted lines) averaged in the Arctic $\left(180^{\circ} \mathrm{W}-180^{\circ} \mathrm{E}, 70-90^{\circ} \mathrm{N}\right)$ between (a) $450 \mathrm{hPa}$ - Tropopause, (b) 450-750 hPa, (c) 750-1000 hPa.

the $\mathrm{LT}, \mathrm{O}_{3}$ TR has a distinctive spring maximum and summer minimum, implying a regime shift from net photochemical production during spring to net destruction in summer in the NH extra-tropics (Yienger et al., 1999).

\subsection{Secondary impact via STT of NO}

In this section, we analyze the GMI results to understand how stratospheric influx of $\mathrm{NO}_{\mathrm{y}}$ affects the photochemical production of ozone in the Arctic troposphere. We define $\mathrm{NO}_{y}$ as the sum of $\mathrm{NO}_{\mathrm{x}}, \mathrm{HNO}_{3}$, peroxyacetyl nitrate (PAN), other organic nitrates, $\mathrm{NO}_{3}, \mathrm{~N}_{2} \mathrm{O}_{5}$, $\mathrm{HONO}$ and $\mathrm{HO}_{2} \mathrm{NO}_{2}$.

Figure 8 shows the seasonal evolution of $\mathrm{NO}_{\mathrm{x}}$ and its important reservoir species, $\mathrm{HNO}_{3}$ and PAN, in the Arctic troposphere. Throughout most of the troposphere, $\mathrm{NO}_{\mathrm{x}}$ is 


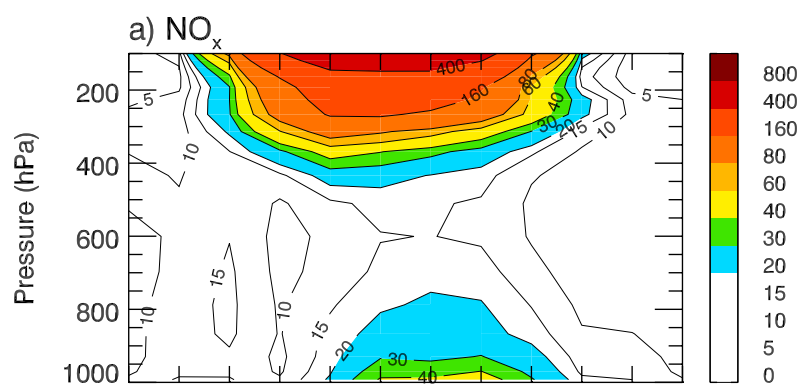

\section{b) $\mathrm{HNO}_{3}$}

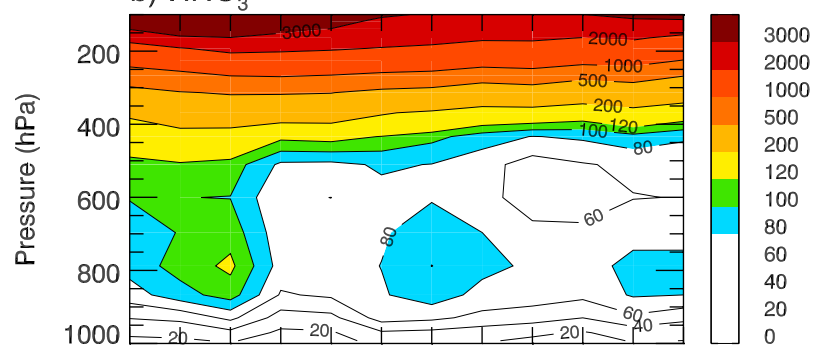

c) PAN

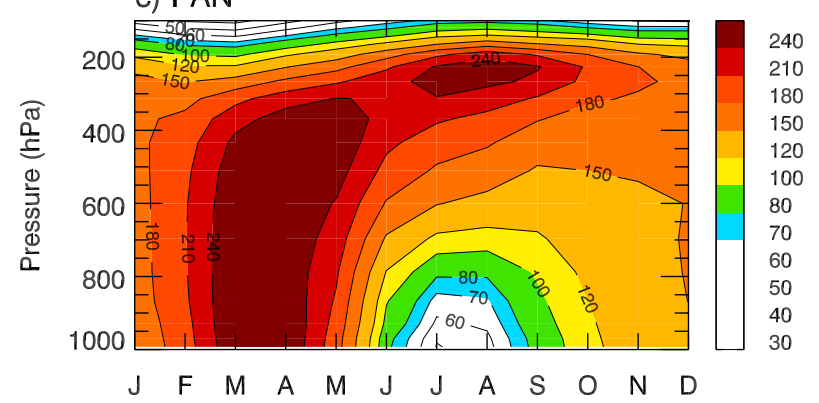

Fig. 8. Seasonal cycle of simulated zonally averaged monthly mean (a) $\mathrm{NO}_{\mathrm{x}}$, (b) $\mathrm{HNO}_{3}$, and (c) PAN in the Arctic $\left(70-90^{\circ} \mathrm{N}\right)$. Units are pptv.

$<20$ pptv in all seasons. Near the surface, $\mathrm{NO}_{\mathrm{x}}$ shows a weak summer maximum with mixing ratios reaching $\sim 30$ 40 pptv. $\mathrm{NO}_{\mathrm{x}}$ in the UT displays a broader spring-early fall maximum, well-connected to the maximum in the $\mathrm{LS}$. $\mathrm{HNO}_{3}$ has a strong vertical gradient with concentrations decreasing rapidly with decreasing altitude $(\sim 1 \mathrm{ppbv}$ at $200 \mathrm{hPa}$ and $\sim 20-40$ pptv at surface). Unlike other trace gases of stratospheric origin, $\mathrm{HNO}_{3}$ shows no significant seasonal variation in the troposphere except a weak maximum in FebruaryMarch in the middle troposphere. PAN is an important tropospheric reservoir species for $\mathrm{NO}_{\mathrm{x}}$. Since PAN can release $\mathrm{NO}_{\mathrm{x}}$ in the remote troposphere via thermal decomposition, it is of particular importance to the secondary production of ozone (Moxim et al., 1996; Schultz et al., 1999). PAN shows a commonly observed spring maximum $(\sim 250 \mathrm{pptv})$ throughout the Arctic troposphere due to wintertime accumulation and active spring photochemical production (e.g. Penkett and Brice, 1986; Honrath and Jaffe, 1992; Jaffe, 1993; Bottenheim et al., 1994). In contrast to the summer mini-

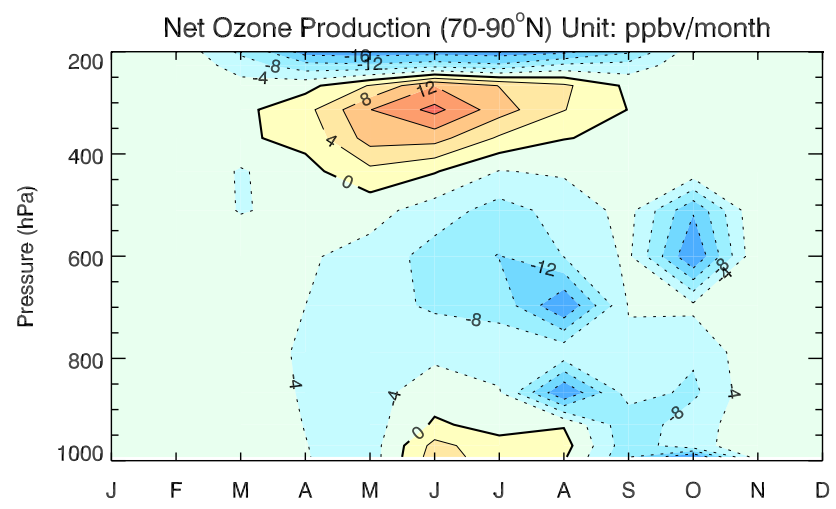

Fig. 9. Seasonal variation of net ozone production in the Arctic.

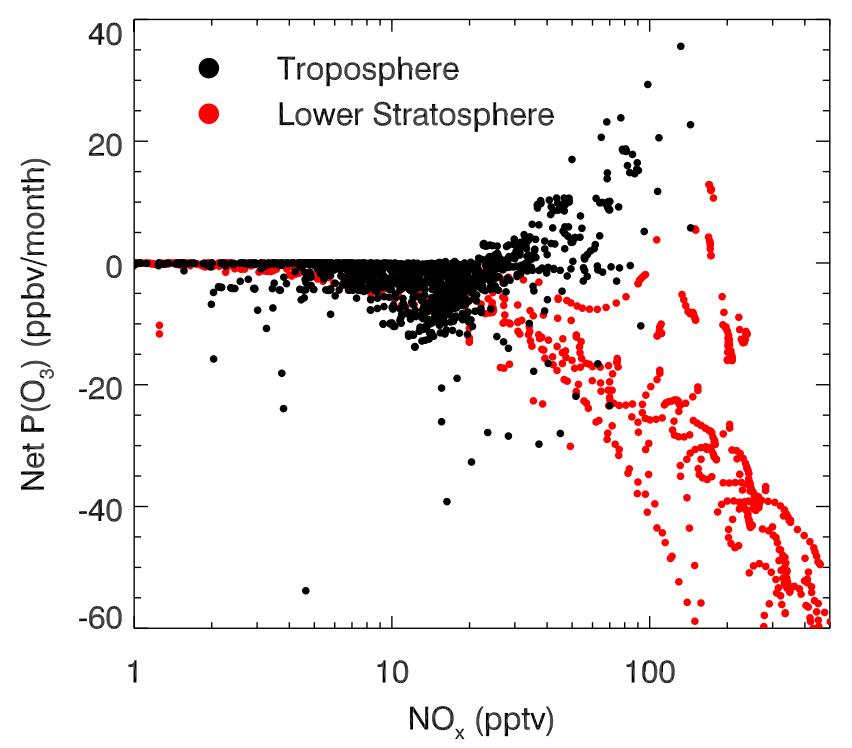

Fig. 10. Scatter plot of net ozone production rates versus NOx in the troposphere (black dots) and the lower stratosphere (red dots) between $70-90^{\circ} \mathrm{N}$.

mum ( $\sim 60$ pptv) near the surface, PAN shows a secondary peak during summer in the UT. Our simulated $\mathrm{NO}_{\mathrm{x}}$ and $\mathrm{NO}_{\mathrm{y}}$ concentrations, seasonality, and $\mathrm{NO}_{\mathrm{y}}$ speciation agree well with ground measurements described in Honrath and Jaffe (1992) and Jaffe (1993), aircraft measurements from the NASA ABLE (Talbot et al., 1992, 1994) and TOPSE missions (Stroud et al., 2003), lending confidence in the $\mathrm{NO}_{\mathrm{x}}$ chemistry in the GMI model.

A small addition in $\mathrm{NO}_{\mathrm{x}}$ can shift the background troposphere from a regime of net photochemical destruction of ozone to one of net production. Figure 9 shows the net ozone production rate, $\mathrm{P}\left(\mathrm{O}_{3}\right)$, from GMI in the Arctic troposphere. In general, photochemical destruction exceeds production and the Arctic troposphere regime is one of net photochemical ozone loss. This is consistent with the springtime measurements from the TOPSE field mission (Cantrell 
et al., 2003). Near the surface, weak net ozone production (0-4 ppbv/month) occurs in summer. Strong net ozone production occurs in the UT in spring and summer with maximum production rates as high as +16 ppbv/month in June. Figure 10 shows the scatter of GMI-simulated $\mathrm{P}\left(\mathrm{O}_{3}\right)$ vs. $\mathrm{NO}_{\mathrm{x}}$ in the Arctic. While $\mathrm{NO}_{\mathrm{x}}$ in the lower stratosphere acts monotonically to destroy ozone, its impact in the troposphere changes significantly due to the increasing importance of its reaction with $\mathrm{HO}_{\mathrm{x}}$. As $\mathrm{NO}_{\mathrm{x}}$ mixing ratio increases from a few pptv to $\sim 100 \mathrm{pptv}$, net ozone production changes from negative values to positive ones. This is similar to the $\mathrm{P}\left(\mathrm{O}_{3}\right)-\mathrm{NO}_{\mathrm{x}}$ relationship observed in the mid-latitude UT during the Subsonic assessment: Ozone and $\mathrm{NO}_{\mathrm{x}}$ experiment (SONEX) (Jaeglé et al., 1999). $\mathrm{NO}_{\mathrm{x}} \sim 20 \mathrm{pptv}$ represents a critical threshold where the Arctic troposphere switches from a regime of net ozone production to net destruction.

We perform a detailed budget analysis of $\mathrm{NO}_{\mathrm{x}}$ and $\mathrm{NO}_{\mathrm{y}}$, including transport and chemical production and loss, in the Arctic UT (450 hPa-tropopause) to examine the impact of STE on $\mathrm{NO}_{\mathrm{x}}$ in the polar troposphere (Fig. 11). Note that emissions from lightning and removal via wet deposition are not shown as these impacts are small in the Arctic UT. $\mathrm{NO}_{\mathrm{y}}$ in the UT shows a prominent seasonal cycle with a spring maximum, similar to the other STE-related chemical species (Fig. 11a). $\mathrm{HNO}_{3}$ and PAN account for 50\% (240 pptv) and $42 \%$ (205 pptv), respectively, of the simulated $\mathrm{NO}_{\mathrm{y}}$ and the remaining is in the form of $\mathrm{NO}_{\mathrm{x}}(25 \mathrm{pptv}, 5 \%)$ and $\mathrm{HO}_{2} \mathrm{NO}_{2}$ (21 pptv, 4\%). The mixing ratios of $\mathrm{NO}_{3}, \mathrm{~N}_{2} \mathrm{O}_{5}$ and $\mathrm{HONO}$ are small. Figure $11 \mathrm{~b}$ shows the monthly gain and loss of $\mathrm{NO}_{\mathrm{y}}$ in the Arctic UT due to vertical transport and horizontal transport from the mid-latitudes. There is a net influx of $\mathrm{NO}_{\mathrm{y}}$ from the mid-latitudes to the polar UT from winter to early spring, mostly in the form of $\mathrm{HNO}_{3}$. However, $\mathrm{NO}_{\mathrm{y}}$ remains relatively constant as this net influx is balanced by either recirculation back to the mid-latitudes (January) or transport to the stratosphere (February-March). Stratospheric influx of $\mathrm{NO}_{\mathrm{y}}\left(80 \%\right.$ in $\mathrm{HNO}_{3}$ and $12 \%$ in $\left.\mathrm{NO}_{\mathrm{x}}\right)$ accompanies the onset of active STE in spring, persisting until mid-fall. Most of the stratospheric influx descends into the MT/LT while a small portion advects to the lower latitudes via horizontal transport.

We calculate the conversion rates between $\mathrm{NO}_{\mathrm{x}}$ and its reservoir species, $\mathrm{HNO}_{3}$ and PAN, using the model archived reaction rates (Fig. 11c). Note that $\mathrm{NO}_{\mathrm{x}}$ is in fast balance with the organic nitrates so that while the conversion between $\mathrm{NO}_{\mathrm{x}}$ and these nitrates are large, the net production of $\mathrm{NO}_{\mathrm{x}}$ is small. Photochemical production and destruction of $\mathrm{NO}_{\mathrm{x}}$ reach a maximum in summer due to higher temperature and more sunlight. In spring, $\mathrm{HNO}_{3}$ photolysis and its reaction with $\mathrm{OH}$ exceed the conversion of $\mathrm{NO}_{\mathrm{x}}$ to $\mathrm{NO}_{\mathrm{y}}$, resulting in net production of $\mathrm{NO}_{\mathrm{x}}$ and a rapid increase in $\mathrm{NO}_{\mathrm{x}}$ mixing ratio. A fraction of this $\mathrm{NO}_{\mathrm{x}}$ reacts with hydrocarbons to form PAN. In summer, the photochemical loss of $\mathrm{NO}_{\mathrm{x}}$ exceeds the photochemical production and $\mathrm{NO}_{\mathrm{x}}$ is converted to $\mathrm{HNO}_{3}$ and PAN. The annual net production of $70-90^{\circ} \mathrm{N}, 450 \mathrm{hPa}$ - Tropopause
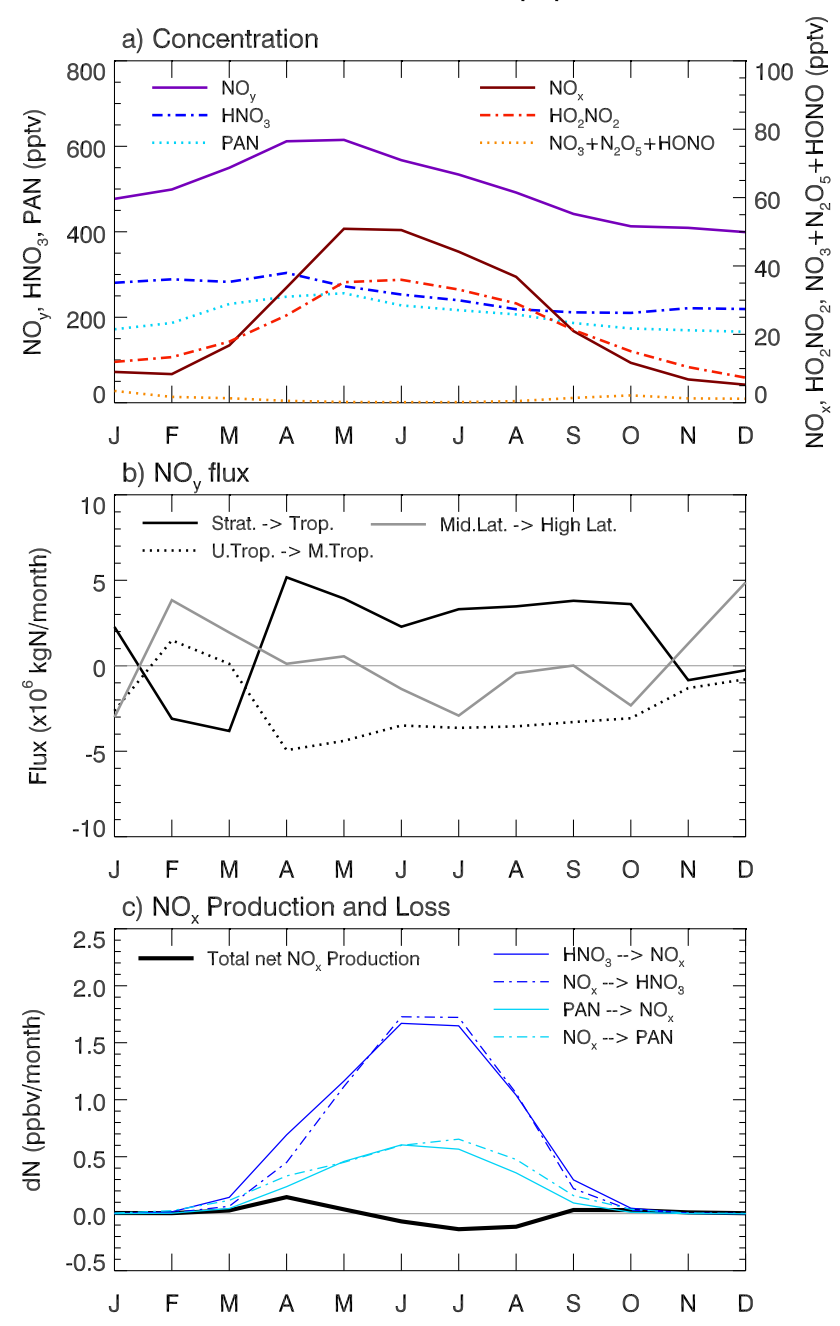

Fig. 11. (a) Seasonal cycle of zonally averaged, monthly mean $\mathrm{NO}_{\mathrm{y}}, \mathrm{HNO}_{3}, \mathrm{PAN}, \mathrm{NO}_{\mathrm{x}}, \mathrm{HNO}_{4}, \mathrm{NO}_{3}+\mathrm{N}_{2} \mathrm{O}_{5}+\mathrm{HNO}_{2}$ averaged in the Arctic UT $\left(70-90^{\circ} \mathrm{N}\right.$ and $450 \mathrm{hPa}$ - tropopause). (b) Vertical and meridional fluxes of $\mathrm{NO}_{\mathrm{y}}$ into the Arctic UT. Note positive values indicate net gain of $\mathrm{NO}_{\mathrm{y}}$ and negative values represent loss. (c) Conversion rates between $\mathrm{NO}_{\mathrm{x}}$ and its reservoir species, $\mathrm{HNO}_{3}$ (blue) and PAN (aqua). Production of $\mathrm{NO}_{\mathrm{x}}$ is plotted as solid lines and loss in dash-dotted lines. Total net $\mathrm{NO}_{\mathrm{x}}$ production from all $\mathrm{NO}_{\mathrm{x}}$-related reactions is plotted as thick black line.

PAN $\left(2.60 \times 10^{6} \mathrm{kgN}\right)$ in the Arctic UT is comparable to that transported from the mid-latitudes $\left(2.66 \times 10^{6} \mathrm{kgN}\right)$. While the spring maximum in PAN is mostly due to transport from the mid-latitudes, the secondary summer peak is a result of in situ production. Most of the PAN in the UT descends into the MT/LT and further enhances ozone production in the Arctic LT via thermal decomposition. This impact can extend as far as the northern mid-latitudes due to Arctic outflow which has been documented by many early studies (Bottenheim and Gallant, 1989; Honrath and Jaffe, 1992; Honrath et al., 1996; Fenneteaux et al., 1999). 


\section{Conclusions}

Stratosphere-to-troposphere transport of ozone is an intricate interplay of dynamics and chemistry. We used the seasonality of atmospheric trace gases, including CFC-11, $\mathrm{O}_{3}$ and dynamic tracers, to examine the dynamics of STE/STT and its influence on the Arctic tropospheric ozone.

The seasonality of the stratospheric contribution of a trace gas in the troposphere is determined by the following factors.

- Seasonality in STE flux. For atmospheric trace gases like $\mathrm{CFC}-12$ and $\mathrm{O}_{3}$, their seasonal cycles in the troposphere due to STE are dominated by the seasonal change in their concentrations in the LS driven by the Brewer-Dobson circulation.

- Latitudinal variation in Seasonality. Due to the differences in STE, fast quasi-horizontal transport in the mid-latitudes versus slow downward penetration in the Arctic, latitudinal differences in the seasonal cycle of a trace gas in the LS can also affect the timing of its seasonal maximum/minimum.

- Tropospheric lifetime. When initialized with the same concentration and seasonal cycle in the LS, trace gases that have a shorter lifetime have smaller stratospheric contributions, smaller amplitudes, and earlier seasonal maxima in the troposphere.

Stratosphere-troposphere exchange (STE) occurs predominantly between $40^{\circ} \mathrm{N}$ to $80^{\circ} \mathrm{N}$. Stratospheric injection in the mid-latitudes accounts for $67-81 \%$ of the stratospheric influence in the NH extratropical troposphere. The mass downward transport across the tropopause and into the LT is slow. The complete transport from the LS to the LT takes three months on average, one month across the tropopause followed by an additional month from the upper troposphere (UT) to the middle troposphere (MT) and a third one from the MT to the LT.

We found that STE contributes to $\mathrm{O}_{3}$ in the Arctic troposphere $\left(70-90^{\circ} \mathrm{N}\right)$ via both direct transport and the secondary production from transport of $\mathrm{NO}_{\mathrm{y}}$. Direct transport of $\mathrm{O}_{3}$ from the stratosphere is the dominant contributor of $\mathrm{O}_{3}$ in the Arctic UT (78\% on annual average) and has a broad spring maximum from March to May. In the MT/LT, stratospheric $\mathrm{O}_{3}$ accounts for $20-25 \%$ of total $\mathrm{O}_{3}$ and shows a very weak spring maximum. The significantly diminished seasonal cycle of stratospheric $\mathrm{O}_{3}$ in the Arctic MT/LT troposphere is a result of a coincident increase of stratospheric input from spring to summer and a decrease in the $\mathrm{O}_{3}$ lifetime from 4 months in spring to $<1$ month in summer

STE also injects $\mathrm{NO}_{y}$-rich air, mostly $\mathrm{HNO}_{3}$, into the UT. This induces an increase in $\mathrm{NO}_{\mathrm{x}}$ above the 20 pptv threshold during spring and summer and subsequently results in a photochemical regime shift from net photochemical ozone destruction to net photochemical production. A fraction of the $\mathrm{NO}_{\mathrm{x}}$ released from $\mathrm{HNO}_{3}$ forms PAN which then descends into the lower altitudes and further enhances tropospheric ozone production via thermal decomposition. $\mathrm{O}_{3}$ produced in this secondary process, together with that from direct transport, is embedded in air masses of stratospheric origin with many tracers, i.e. CFCs and $\mathrm{NO}_{\mathrm{y}}$, displaying significant stratospheric characteristics. The mixture starts from the UT in spring and descends slowly, reaching the MT/LT in summer. This conceptual model provides a good explanation of the intriguing seasonality of stratospheric influences observed during many previous aircraft missions.

Although $\mathrm{O}_{3}$ shows a spring maximum throughout the Arctic troposphere, this maximum is associated with different processes at different altitudes. The spring peak in the UT is due to maximum STT while the peak in the MT/LT is mostly the result of in situ photochemistry.

Acknowledgements. This research was supported by an appointment to the NASA Postdoctoral Program at the Goddard Space Flight Center, administered by Oak Ridge Associated Universities through a contract with NASA. We are grateful to Peter Bernath and the ACE team for their data which is important for our model validation in the Arctic. The ACE mission is funded primarily by the Canadian Space Agency.

Edited by: A. Stohl

\section{References}

Atlas, E. L., Ridley, B. A., and Cantrell, C. A.: The Tropospheric Ozone Production about the Spring Equinox (TOPSE) Experiment: Introduction, J. Geophys. Res., 108(D4), 8353, doi:10.1029/2002JD003172, 2003.

Bernath, P. F., McElroy, C. T., Abrams, M. C., et al.: Atmospheric Chemistry Experiment (ACE): Mission overview, Geophys. Res. Lett., 32, L15S01, doi:10.1029/2005GL022386, 2005.

Bey, I., Jacob, D. J., Yantosca, R. M., Logan, J. A., Field, B. D., Fiore, A. M., Li, Q., Liu, H., Mickley, L. J., and Schultz, M. G.: Global modeling of tropospheric chemistry with assimilated meteorology: Model description and evaluation, J. Geophys. Res., 106(D19), 23073-23095, 2001.

Bian, H., and Prather, M. J.: Fast-J2: Accurate Simulation of stratospheric photolysis in global chemical models, J. Atmos. Chem., 41, 281-296, 2002.

Bloom, S., da Silva, A., Dee, D., et al.: The Goddard Earth Observation System Data Assimilation System, GEOS DAS version 4.0.3: Documentation and validation, NASA Tech. Memo., TM2005-104606, 26, 166 pp., 2005.

Bottenheim, J. W., Gallant, A. G., and Brice, K. A.: Measurements of $\mathrm{NO}_{\mathrm{y}}$ species and $\mathrm{O}_{3}$ at $82^{\circ} \mathrm{N}$ Latitude, Geophys. Res. Lett., 12, 113-116, 1986.

Bottenheim, J. W. and Gallant, A. G.: PAN over the Arctic: Observations during AGASP-2 in April 1986, J. Atmos. Chem., 9, 301-306, 1989.

Bottenheim, J. W., Sirois, A., Brice, K. A., and Gallant, A. J.: Five years of continuous observations of PAN and ozone at a rural location in eastern Canada, Geophys. Res. Lett., 13(2), 113-116, 1994. 
Browell, E. V., Butler, C. F., Kooi, S. A., Fenn, M. A., Harriss, R. C., and Gregory, G. L.: Large-Scale Variability of Ozone and Aerosols in the Summertime Arctic and Sub-Arctic Troposphere, J. Geophys. Res., 97(D15), 16433-16450, 1992.

Browell, E. V., Fenn, M. A., Butler, C. F., Grant, W. B., Harriss, R. C., and Shipham, M. C.: Ozone and aerosol distributions in the summertime troposphere over Canada, J. Geophys. Res., 99(D1), 1739-1755, 1994.

Browell, E. V., Hair, J. W., Butler, C. F., et al.: Ozone, aerosol, potential vorticity, and trace gas trends observed at high-latitudes over North America from February to May 2000, J. Geophys. Res., 108(D4), 8369, doi:10.1029/2001JD001390, 2003.

Browning, K. A.: The dry intrusion perspective of extratropical cyclone development, Meteorol. Appl., 4, 317-324, 1997.

Cantrell, C. A., Mauldin, L., Zondlo, M., et al.: Steady state free radical budgets and ozone photochemistry during TOPSE, J. Geophys. Res., 108(D4), 8361, doi:10.1029/2002JD002198, 2003.

Chin, M., Ginoux, P., Kinne, S., Torres, O., Holben, B. N., Duncan, B. N., Martin, R. V., Logan, J. A., Higurashi, A., and Nakajima, T.: Tropospheric aerosol optical thickness from the GOCART model and comparisons with satellite and sunphotometer measurements, J. Atmos. Sci., 59, 461-483, 2002.

Cooper, O. R., Moody, J. L., Parrish, D. D., Trainer, M., Ryerson, T. B., Holloway, J. S., Hübler, G., Fehsenfeld, F. C., Oltmans, S. J., and Evans, M. J.: Trace gas signatures of the airstreams within North Atlantic cyclones: Case studies from the North Atlantic Regional Experiment (NARE '97) aircraft intensive, J. Geophys. Res., 106(D6), 5437-5456, 2001.

Cotton, W. R., Alexander, G. D., Hertenstein, R., Walko, R. L., McAnelly, R. L., and Nicholls, M.: Cloud venting - A review and some new global annual estimates, Earth Sci. Rev., 39, 169206, 1995.

Danielsen, E. F. and Mohnen, V.: Project dust storm report: ozone transport, in situ measurements and meteorological analysis of tropopause folding, J. Geophys. Res., 82, 5867-5877, 1977.

Dethof, A., O'Neill, A., and Slingo, J.: Quantification of the isentropic mass transport across the dynamical tropopause, J. Geophys. Res., 105, 12279-12293, 2000.

Dewent, R. G., Simmonds, P. G., Seuring, S., and Dimmer, C.: Observation and interpretation of the seasonal cycles in the surface concentrations of ozone and carbon monoxide at Mace Hear, Ireland from 1990 to 1994, Atmos. Environ., 32, 145-157, 1998.

Dibb, J. E., Talbot, R. W., and Gregory, G. L.: ${ }^{7} \mathrm{Be}$ and ${ }^{210} \mathrm{~Pb}$ in the western hemisphere Arctic atmosphere: Observations from three recent aircraft-based sampling programs, J. Geophys. Res., 97, 16709-16715, 1992.

Dibb, J. E., Meeker, L. D., Finkel, R. C., Southon, J. R., Caffee, M. W., and Barrie, L. A.: Estimation of stratospheric input to the Arctic troposphere: ${ }^{7} \mathrm{Be}$ and ${ }^{10} \mathrm{Be}$ in aerosols at Alert, Canada, J. Geophys. Res., 99(D6), 12855-12864, 1994.

Douglass A. R., Stolarski, R. S., Strahan, S. E., and Connell, P. S.: Radicals and reservoirs in the GMI chemistry and transport model: Comparison to measurements, J. Geophys. Res., 109, D16302, doi:10.1029/2004JD004632, 2004.

Douglass, A. R., Stolarski, R. S., Schoeberl, M. R., Jackman, C. H., Gupta, M. L., Newman, P. A., Nielsen, J. E., and Fleming, E. L.: Relationship of loss, mean age of air and the distribution of CFCs to stratospheric circulation and implica- tions for atmospheric lifetimes, J. Geophys. Res., 113, D14309, doi:10.1029/2007JD009575, 2008.

Duncan, B. N., Martin, R. V., Staudt, A. C., Yevich, R., and Logan, J. A.: Interannual and seasonal variability of biomass burning emissions constrained by satellite observations, J. Geophys. Res., 108(D2), 4100, doi:10.1029/2002JD002378, 2003

Duncan, B. N., Strahan, S. E., Yoshida, Y., Steenrod, S. D., and Livesey, N. J.: Model Study of the Cross-Tropopause Transport of Biomass Burning Pollution, Atmos. Chem. Phys., 7, 37133736, 2007a, http://www.atmos-chem-phys.net/7/3713/2007/.

Duncan, B. N., Logan, J. A., Bey, I., Megretskaia, I. A., Yantosca, R. M., Novelli, P. C., Jones, N. B., and Rinsland, C. P. The global budget of CO, 1988-1997: source estimates and validation with a global model, J. Geophys. Res., 112, D22301, doi:10.1029/2007JD008459, 2007b.

Fenneteaux, I., Colin, P., Etienne, A., Boudries, H., Dutot, A. L., Perros, P. E., and Toupance, G.: Influence of continental sources on oceanic air composition at the eastern edge of the North Atlantic Ocean, TOR 1992-1995, J. Atmos. Chem., 32, 233-280, 1999.

Fry, L. M., Jew, F. A., and Kuroda, P. K.: On the stratospheric fallout of strontium 90: the spring peak of 1959, J. Geophys. Res., 65, 2061-2066, 1960.

Hack, J. J: Parameterization of moist convection in the NCAR Community Climate Model, CCM2, J. Geophys. Res., 99, 55515568, 1994.

Harriss, R. C., Wofsy, S. C., Bartlett, D. S., et al.: The Arctic Boundary Layer Expedition (ABLE-3A): July-August 1988, J. Geophys. Res., 97, 16383-16394, 1992.

Harriss, R. C., Wofsy, S. C., Hoell Jr., J. M., Bendura, R. J., Drewry, J. W., McNeal, R. J., Pierce, D., Rabine, V., and Snell, R. L.: The Arctic Boundary layer Expedition (ABLE 3B): July-August 1990, J. Geophys. Res., 99(D1), 1635-1643, 1994.

Haynes, P. H., Marks, C. J., McIntyre, M. E., Sheperd, T. G., and Shine, K. P.: On the "downward control" of extratropical diabatic circulations by eddy-induced mean zonal forces, J. Atmos. Sci., 48, 651-678, 1991.

Holton, J. R., Haynes, P. H., McIntyre, M. E., Douglass, A. R., Rood, R. B., and Pfister, L.: Stratosphere-troposphere exchange, Rev. Geophys., 33, 403-439, 1995.

Honrath, R. E. and Jaffe, D. A.: The seasonal cycle of nitrogen oxides in the Arctic troposphere at Barrow, Alaska, J. Geophys. Res., 97, 20615-20630, 1992.

Honrath, R. E., Hamlin, A. J., and Merrill, J. T.: Transport of ozone precursors from the Arctic troposphere to the North Atlantic region, J. Geophys. Res., 101, 29335-29351, 1996.

Hsu, J., Prather, M. J., and Wild, O.: Diagnosing the stratosphereto-troposphere flux of ozone in a chemistry transport model, J. Geophys. Res., 110, D19305, doi:10.1029/2005JD006045, 2005.

Jaeglé, L., Jacob, D. J., Brune, W. H., et al.: Ozone production in the upper troposphere and the influence of aircraft during SONEX: Approach of NOx-saturated conditions, Geophys. Res. Lett., 26, 3081-3084, 1999.

Jaffe, D. A.: The relationship between anthropogenic nitrogen oxides and ozone trends in the Arctic troposphere, in: The Tropospheric Chemistry of Ozone in the Polar Regions, edited by: Niki, H. and Becker, K. H., NATO ASI Ser., Ser. 1, 7, 105-115, 1993. 
James, P., Stohl, A., Forster, C., Eckhardt, S., Seibert, P., and Frank, A.: A 15-year climatology of stratosphere\&\#8211;troposphere exchange with a Lagrangian particle dispersion model, 2, Mean climate and seasonal variability, J. Geophys. Res., 108(D12), 8522, doi:10.1029/2002JD002639, 2003.

Klonecki, A. A., and Hevy, H., II: Tropospheric chemical ozone tendencies in the CO-CH4-NOy-H2O system: Their sensitivity to variations in environmental parameters and their application to a GCTM study, J. Geophys. Res., 102, 21221-21237, 1997.

Levy II, H., Mahlman, J., Moxim, W. J., and Liu, S. C.: Tropospheric ozone: the role of transport, J. Geophys. Res., 90, 37533772, 1985.

Levy, H., II, Moxim, W. J., Klonecki, A. A., and Kasibhatla, P. S.: Simulated tropospheric NOx: Its evaluation, global distribution and individual source contributions, J. Geophys. Res., 104, 26279-26306, 1999.

Liang, Q., Jaeglé, L., Hudman, R. C., et al.: Summertime influence of Asian pollution in the free troposphere over North America, J. Geophys. Res., 112, D12S11, doi:10.1029/2006JD007919, 2007.

Liang, Q., Stolarski, R. S., Douglass, A. R., Newman, P. A., and Nielsen, J. E.: Evaluation of emissions and transport of CFCs using surface observations and their seasonal cycles and the GEOS CCM simulation with emissions-based forcing, J. Geophys. Res., 113, D14302, doi:10.1029/2007JD009617, 2008.

Lin, X., Trainer, M., and Liu, S. C.: On the nonlinearity of the tropospheric ozone production, J. Geophys. Res., 93, 15879-15888, 1988.

Lin, S.-J. and Rood, R. B.: Multidimensional flux-form semiLagrangian transport schemes, Mon. Weather Rev., 124, 20462070, 1996.

Liu, S. C., Trainer, M., Fehsenfeld, F. C., Parrish, D. D., Williams, E. J., Fahey, D. W., Hubler, G., and Murphy, P. C.: Ozone production in the rural troposphere and the implications for regional and global ozone distributions, J. Geophys. Res., 92, 4191-4207, 1987.

Logan, J. A.: Tropospheric ozone: seasonal behavior, trends, and anthropogenic influence, J. Geophys. Res., 90(D6), 1046310482, 1985.

Logan, J. A.: An analysis of ozonesonde data for the troposphere: recommendations for testing 3-D models and development of a gridded climatology for tropospheric ozone, J. Geosphys. Res., 104, 16115-16149, 1999.

Marcy, T. P., Fahey, D. W., Gao, R. S., et al.: Quantifying Stratospheric Ozone in the Upper Troposphere with in Situ Measurements of $\mathrm{HCl}$, Science, 304, 261-265, doi:10.1126/science.1093418, 2004.

Monks, P. S.: A review of the observations and origins of the spring ozone maximum, Atmos. Environ., 34, 3545-3561, 2000.

Montzka, S. A., Butler, J. H., Elkins, J. W., Thompson, T. M., Clarke, A. D., and Lock, L. T.: Present and future trends in the atmospheric burden of ozone-depleting halogens, Nature, 398(6729), 690-694, 1999.

Moxim, W. J., Levy II, H., and Kasibhatla, P. S.: Simulated global tropospheric PAN: Its transport and impact on $\mathrm{NO}_{\mathrm{x}}, \mathrm{J}$. Geophys. Res., 101, 12621-12638, 1996.

Nevison, C. D., Kinnison, D. E., and Weiss, R. F.: Stratospheric influences on the tropospheric seasonal cycles of nitrous oxide and chlorofluorocarbons, Geophys. Res. Lett., 31, L20103,
doi:10.1029/2004GL020398, 2004.

Olsen, M. A., Schoeberl, M. R., and Douglass, A. R.: Stratospheretroposphere exchange of mass and ozone, J. Geophys. Res., 109, D24114, doi:10.1029/2004JD005186, 2004.

Oltmans, S. J.: Surface ozone measurements in clean air, J. Geophys. Res., 86, 1174-1180, 1981.

Oltmans, S. J. and Levy III, H.: Surface ozone measurements from a global network, Atmos. Environ., 28, 9-24, 1994.

Pawson, S, Stajner, I., Kawa, S. R., Hayashi, H., Tan, W.W., Nielsen, J. E., Zhu, Z., Chang, L.-P., and Livesey, N. J.: Stratospheric transport using 6-h-averaged winds from a data assimilation system, J. Geophys. Res., 112, D23103, doi:10.1029/2006JD007673, 2007.

Pawson, S., Stolarski, R. S., Douglass, A. R., Newman, P. A., Nielsen, J. E., Frith, S. M., and Gupta, M. L.: Goddard Earth Observing System Chemistry-Climate Model Simulations of Stratospheric Ozone-Temperature Coupling Between 1950 and 2005, J. Geophys. Res. 113, D12103, doi:10.1029/2007JD009511, 2008.

Penkett, S. A., and Brice, K. A.: The spring maximum in photooxidants in the Northern Hemisphere troposphere, Nature, 319, 655-657, 1986.

Prinn, R. G., Weiss, R. F., Fraser, P. J., et al.: A history of chemically and radiatively important gases in air deduced from ALE/GAGE/AGAGE, J. Geophys. Res., 105, 17751-17792, 2000.

Rasch, P. J., Mahowald, N. M., and Eaton, B. E.: Representations of transport, convection, and the hydrologic cycle in chemical transport models: Implications for the modeling of short-lived and soluble species, J. Geophys. Res., 102, 28127-28138, 1997.

Rosenfield, J. E., Newman, P. A., and Schoeberl, M. R.: Computations of diabatic descent in the stratospheric polar vortex, J. Geophys. Res., 99, D8, 16677-16689, 1994.

Schoeberl, M. R.: Extratropical stratosphere-troposphere mass exchange, J. Geophys. Research, 109, D13303, doi:10.1029/2004JD004525, 2004.

Schultz, M., Jacob, D. J., Wang, Y., et al.: On the origin of tropospheric ozone and NOx over the tropical South Pacific, J. Geophys. Res., 104, 5829-5843, 1999.

Seinfeld, J. H. and Pandis, S. N.: Atmospheric chemistry and physics: From air pollution to climate change, A WileyInterscience publication, 258-259, 1997.

Shapiro, M. A., Hampel, T., and Krueger, A. J.: The Arctic Tropopause Fold, Month. Wea. Rev., 115, 2, 444-454, 1987.

Shindell, D., Faluvegi, G., Lacis, A., Hansen, J., Ruedy, R., and Aguilar, E.: Role of tropospheric ozone increases in 20th-century climate change, J. Geophys. Res., 111, D08302, doi:10.1029/2005JD006348, 2006.

Shipham, M. C., Bachmeier, A. S., Cahoon, D. R., and Browell, E. V.: Meteorological Overview of the Arctic Boundary Layer Expedition (ABLE 3A) Flight Series, J. Geophys. Res., 97(D15), 16395-16419, 1992.

Sillman, S., Logan, J. A., and Wofsy, S. C.: The sensitivity of ozone to nitrogen oxides and hydrocarbons in regional ozone episodes, J. Geophys. Res., 95, 1837-1852, 1990.

Simmonds, P. G., Seuring, S., Nickels, G., and Derwent, R. G.: Segregation and interpretation of ozone and carbon monoxide measurements by air mass origin at the TOR station Mace Head, Ireland from 1987 to 1995, J. Atmos. Chem., 28, 45-59, 1997. 
Stohl, A.: A1-year Lagrangian "climatology" of airstreams in the Northern Hemisphere troposphere and lowermost stratosphere, J. Geophys. Res., 106(D7), 7263-7279, 2001.

Stohl, A.: Characteristics of atmospheric transport into the Arctic troposphere, J. Geophys. Res., 111, D11306, doi:10.1029/2005JD006888, 2006.

Stohl, A., Wernli, H., James, P., Bourqui, M., Forster, C., Liniger M. A., Seibert, P., and Sprenger, M.: A new perspective of stratosphere-troposphere exchange, B. American Meteor. Soc., 84(11), 1565-1573, 2003.

Stolarski, R. S., Douglass, A. R., Steenrod, S., and Pawson, S.: Trends in stratospheric ozone: Lessons learned from a 3D chemical transport model, J. Atmos. Sci., 63, 1028-1041, 2006.

Strahan, S. E. and Douglass, A. R.: Evaluating the credibility of transport processes in simulations of ozone recovery using the Global Modeling Initiative three-dimensional model, J. Geophys. Res., 109, D05110, doi:10.1029/2003JD004238, 2004.

Stroud, C., Madronich, S., Atlas, E., et al.: Photochemistry in the arctic free troposphere: $\mathrm{NO}_{\mathrm{x}}$ budget and the role of odd nitrogen reservoir recycling, Atmos. Environ., 37, 3351-3364, 2003.

Talbot, R. W., Vijgen, A. S., and Harriss, R. C.: Soluble species in the Arctic summer troposphere: Acidic gases, aerosols, and precipitation, J. Geophys. Res., 97, 16531-16543, 1992.

Talbot, R. W., Bradshaw, J. D., Sanholm, S. T., et al.: Summertime distribution and relations of reactive odd nitrogen species and NOy in the troposphere over Canada, J. Geophys. Res., 99(D1), 1863-1885, 1994.

Thompson, T. M., Butler, J. H., Daube, B. C., et al.: Halocarbons and other atmospheric trace species, Summary Rep. 27 20022003, edited by Schnell, R. C., Buggle, A.-M., and Rossen, R., Clim. Monit. Diagn. Lab., US Dep. Of Commer., Boulder, Colorado, USA, 115-135, 2004.
Thompson, A. M., Stone, J. B., Witte, J. C., et al.: Intercontinental Chemical Transport Experiment Ozonesonde Network Study (IONS) 2004: 1. Summertime upper troposphere/lower stratosphere ozone over northeastern North America, J. Geophys. Res., 112, D12S12, doi:10.1029/2006JD007441, 2007.

Toon, G. C.: The JPL MkIV interferometer, Opt. Photonic News, 2, 19-21, 1991.

Wang, Y., Jacob, D. J., and Logan, J. A., Global simulation of tropospheric $\mathrm{O}_{3}-\mathrm{NO}_{\mathrm{X}}$-hydrocarbon chemistry: 3. Origin of tropospheric ozone and effects of nonmethane hydrocarbons, J. Geophys. Res., 103, 10757-10767, 1998.

Wang, Y., Ridley, B., Fried, A., et al.: Springtime photochemistry at northern mid and high latitudes, J. Geophys. Res., 108(D4), 8358, doi:10.1029/2002JD002227, 2003.

Yang, H. and Tung, K. K.: Cross-isentropic stratospheretroposphere exchange of mass and water vapor, J. Geophys. Res., 101, 9413-9423,1996.

Yevich, R. and Logan, J. A.: An assessment of biofuel use and burning of agricultural waste in the developing world, Global Biogeochem. Cy., 17(4), 1095, doi:10.1029/2002GB001952, 2003.

Yienger, J. J., Klonecki, A. A., Levy, H. II, Moxim, W. J., and Carmichael, G. R.: An evaluation of chemistry's role in the winter-spring ozone maximum found in the northern mid-latitude free troposphere, J. Geophys. Res., 104, 3655-3667, 1999.

Zhang, G. J. and N. A. McFarlane, N. A.: Sensitivity of climate simulations to the parameterization of cumulus convection in the Canadian Climate Centre general circulation model, Atmos. Ocean, 33, 407-446, 1995. 